\title{
Risk Factor Analysis of Salmonella Typhimurium, Staphylococcus aureus, Standard Plate Count and Somatic Cell Count in Bulk Tank Milk in Cattle Dairies
}

\author{
M.F. Azooz ${ }^{1 *}$, Safaa A. El-Wakeel ${ }^{2}$, and H.M. Yousef ${ }^{3}$ \\ ${ }^{l}$ Central Laboratory for Evaluation of Veterinary Biologics (CLEVB), El-Seka El-Baeda St., Abbasia, P.O. Box 131, Egypt \\ ${ }^{2}$ Animal Reproduction Research Institute (ARRI), 5 Garden Center Research Street Haram - Giza, Egypt ${ }^{3}$ Department of Infectious Diseases, Faculty \\ of Veterinary Medicine, Cairo University, El-Shaheed Gamal El-Deen Afify street, Giza square, P.O. Box1221, Giza, Egypt \\ *Corresponding author's Email: mohamed.azzoz.74@gmail.com; (DORCiD: 0000-00024393-4036
}

\begin{abstract}
Bulk tank milk analysis was referred to as a useful and appropriate diagnostic tool to evaluate milk quality and mastitis pathogens in cattle dairy herds. Out of the total number of 150 pooled tank milk samples collected from 150 cattle dairy farms, 13 locally field Staphylococcus aureus isolates were detected and confirmed phenotypically by culturing, gram staining, biochemical, and molecular identification to be Staphylococcus aureus in the overall herd by the prevalence of $8.6 \%$. Isolation and identification of Salmonella Typhimurium field isolates from bulk tank milk samples revealed that 20 locally field isolates were detected and confirmed phenotypically by culturing, gram staining, biochemical and molecular identification to be Salmonella Typhimurium in the overall herd by the prevalence of $13.3 \%$. The results of total bacterial plate count $(\mathrm{cfu} / \mathrm{ml})$ revealed that the geometric mean of 150 dairy farms was $3.2 \times 10^{8} \mathrm{cfu} / \mathrm{ml}$. The geometric mean of somatic cell count (SCC)/ml in Bulk tank milk samples of 150 cattle dairy farms were $556.7 \times 10^{3}$. The geometric mean value of Staphylococcus aureus count in this study was $3.7 \times 10^{3} \mathrm{cfu} / \mathrm{ml}$. Serological identification of the 20 isolates revealed that they were Salmonella Typhimurium. The study provided various risk factors that had a clear and effective role in determining the level of Salmonella Typhimurium, Staphylococcus aureus, Standard plate count, and Somatic cell count in bulk tank milk. The PCR amplification with $(h l g)$ gene-specific primers revealed a product with an approximate size of $937 \mathrm{bp}$. $(h l g)$ gene found in $13(54 \%)$ Staphylococcus aureus isolates. The PCR identification of $\operatorname{sopB}($ SigD) virulence gene for Salmonella Typhimuriym revealed a product with an approximate size of $517 \mathrm{bp}$. SopB gene found in all Salmonella Typhimurium isolates (100\%). Phylogenetic and partial gene sequence analysis of (hlg) Staphylococcus aureus gene of Egyptian isolated strain showed a great identity with the different Staphylococcus aureus strains uploaded from the gene bank. Phylogenetic analysis of Salmonella Typhimurium (sopB) virulence gene of Egyptian isolated strain indicated a great homology with the different Salmonella Typhimurium strains uploaded from the gene banks. The results of the present study emphasize the importance of more efficacious preventive programs for controlling the mastitis and bacteriological quality of bulk tank milk and monitoring mastitis economic losses.
\end{abstract}

Keywords: Mastitis, PCR, Phylogenetic analysis, Risk factors, Salmonella and Staphylococcus aureus

\section{INTRODUCTION}

The using of continuous and regular methods for monitoring and assessing udder health is extremely useful for improvements of udder health status, milk quality premiums programs. The regular assessment of bulk tank milk (BTM) analysis is regarded as one of the foremost significant tools to give insight and perception from the udder health status, and also the proper application of sanitary and hygienic measures in dairy herds, (Jayarao and Wolfgang, 2003). Bulk tank milk analysis is one of the most important diagnostic method for assessment of milk quality and mastitis pathogens (Godkin et al., 1993; Riekerink et al. 2006). There are numerous diagnostic tests commonly used to quantify and assess the quality of BTM, such as Somatic cell count (SCC) and standard plate count (SPC) (Cicconi-Hogan et al., 2012). The SPC assesses the bacterial count in the milk, and estimates the number of aerobic bacteria present per milliliter of milk. SPC is considered one of the foremost important tools to assess management and milk quality, as reported and described in previous studies and milk quality management recommendations (Schroeder, 2009). A high bulk tank SPC can be a consequence of bacteria from dirty milking equipment, milk from cows with subclinical or clinical mastitis, or contamination from dirty udders (Murphy and Boor, 2000). The regulatory cut-off for SPC was 100,000 cfu/mL (Cicconi-Hogan et al., 2012). Quantifying and determining of bulk milk SCC is an internationally recognized diagnostic tool to determine the quality of the milk and also the udder health status of the cattle within the herd. Many management practices were related to higher bulk milk SCC (BMSCC) (Schukken et al. 2003). Milk borne pathogens including Salmonella and Staphylococcus aureus were identified by several researches in BTM with various prevalence rates from dairy farms (Ruzante et al., 2010; Cicconi-Hogan et al., 2012). Salmonella was thought to be one of the main important 
and significant food borne bacterial diseases worldwide. Risk factors related to incidence of Salmonella in BTM was not previously identified. Fecal contamination related to poor milking hygiene was considered one of the most important causes of bulk tank contamination with Salmonella (Van Kessel et al. 2004). The effector protein genes sopB were located in numerous regions of the Salmonella chromosome, and were present in a wide range of Salmonella serotypes, supposing that this effector protein may play vital virulence functions (Mirold et al., 2001). Staphylococcus aureus was regarded as one in all of the most important contagious mastitis pathogens in dairy cattle, and was related to large economic losses (Halasa et al., 2007; Hogeveen et al., 2011; Keefe, 2012). Hemolysins produced by Staphylococcus aureus are very vital virulence factor, with cytotoxic action responsible and answerable for lysing erythrocytes, and it results in worsening of clinical signs during blood stream infections (Duan et al., 2018). The Staphylococcus aureus gamma-hemolysin contains two polypeptides, whereas the gamma-hemolysin locus ( $h l g$ ) has three open reading frames (Cooney et al., 1993). Phylogenetic methods can be used to analyze nucleotide sequence data in such a way that the order of descent of related strains can be determined (Hall and Barlow, 2006). So the aim of this study is to quantify and determine the prevalence of Salmonella Typhimurium and Staphylococcus aureus in the BTM in cattle dairies, identifying the most important risk factors affecting the level of SPC, SCC, in BTM in cattle Dairies, identifying the most important risk factors affecting prevalence of Salmonella Typhimurium and Staphylococcus aureus in bulk tank milk in cattle dairies, molecular identification of sopB gene of Salmonella Typhimurium and hlg gene of Staphylococcus aureus, phylogenetic and gene sequence analysis of sopB gene of Salmonella Typhimurium and hlg gene of Staphylococcus aureus to give insight to the source and origin, molecular epidemiology and disease pattern of Salmonella Typhimurium and Staphylococcus aureus in Egypt's dairies.

\section{MATERIALS AND METHODS}

\section{Ethical approval}

The approval from the Institutional Animal Ethics Committee to hold out this study wasn't required as not contact and no invasive procedure on the animals were performed. However, current study was applied in accordance to the Institutional Animal Ethics of Animal Reproduction Research Institute (ARRI), Haram, Giza, Agricultural Research Center (ARC), and in accordance to the regulations and ethics of the European Union for the protection of experimental animals (2010/63/EU).

\section{Study animals, study area and study design}

A cross-sectional study was carried out from 2017 to 2019 in Delta region, Alexandria Road and upper and lower Egypt Districts from total number of one hundred and fifty (150) private dairy cattle farms with total population number of 8667 lactating cows belonging to Cairo, Giza, Qaluiobia, Sharkia, Monofia, Alexandria, Behera, Dakahlia, Benisuif, Fayoum, Sohag, Aswan and Asuit governorates.

\section{Bulk tank milk sample collection and testing}

A total number of 150 BTM samples were collected. The BTM samples were intended for checking the hygienic quality of raw milk collected in accordance to the standard methods described according to ISO707 (2008). After turning on the agitator for at least 10 minutes, 60ml BTM samples were collected from the top of the bulk tank using clean sanitized dipper. Samples were immediately refrigerated and transported to the laboratory in ice box, and examined within 24 hours after collection.

\section{Microbiological examination of bulk tank milk samples}

Preparation of serial dilution was carried out in accordance to methods described by APHA (1992) and APHA (2004). One ml completely mixed milk sample was transferred under aseptic conditions to $9 \mathrm{ml}$ of sterile $1 / 4$ strength Ringer's solution, and well mixed to urge 1/10 dilution. One $\mathrm{ml}$ from the first dilution was added to $9 \mathrm{ml}$ of sterilized diluents to obtain tenth fold serial dilutions. The previous prepared dilutions were subjected to the subsequent microbiological examinations: The Total Bacterial Plate Count (TBPC) (cfu/ml) was assessed according to the methods descried by APHA (1992) and BAM on line (2009). Two ml of every previously prepared decimal dilution were inoculated into duplicate plates (one $\mathrm{ml}$ each), then 12 to $15 \mathrm{ml}$ of Standard Plate Count Agar medium (Oxoid, CM0463) was added (cooled to $45 \pm 1{ }^{\circ} \mathrm{C}$ ) into each plate as well as control one. The plates were thoroughly mixed and incubated for $48 \pm 2$ hours at $35^{\circ} \mathrm{C}$. Colony Forming Unit (CFU) per ml was calculated and recorded. The standard cut-off for SPC is $100,000 \mathrm{cfu} / \mathrm{mL}$, in accordance with the European Union standards (Cicconi-Hogan et al., 2012). Analysis of BTM samples for SCC was performed according to the methods described by Zecconi et al. (2002). The SCC was quantified and measured using the electronic soma count 150, from Bentley (Chaska, MN 55318, United States). The standard cut off point of BSCC was 400, $000 \mathrm{cell} / \mathrm{ml}$ according to the regulations described by USDA (2011). 
Staphylococcus aureus count (cfu/ml) was assessed as reported by the methods illustrated by ISO 6888-1(1999) and ICMF (1986). From each dilution, $0.1 \mathrm{ml}$ was inoculated onto Baird parker agar plate. Inoculated plates were then incubated at $37{ }^{\circ} \mathrm{C}$ for 48 hours. Typical colonies of Staphylococcus aureus were enumerated, and therefore the average number per ml was calculated. Isolation and identification of Staphylococcus aureus was carried as stated in Quinn et al. (2002) and BAM on line (2009). Pure separated suspected colonies of Staphylococcus aureus were picked up from Baird-Parker agar plates, transferred to nutrient agar slants, and incubated at $37{ }^{\circ} \mathrm{C}$ for 24 hours. The isolated Staphylococcus aureus isolates were identified by Microscopic examination and Biochemical reactions. Biochemical tests used to confirm Staphylococcus aureus were coagulase test, catalase test, indole production, methyl red test, Voges-proskauer reaction, urease production, citrate utilization and sugar fermentation as stated in Toply and Wilsons (1993), colle et al. (1996), Harrigan (1998) and Quinn et al. (2002). Phenotypic characterization of some virulence factors was carried out to detect coagulase test according to methods described by Quinn et al. (2002), and hemolysis assay according to methods described by Koneman et al. (1997). Isolation and identification of Salmonella Typhimurium was carried out according to methods described by ISO-6579 (2002). Five ml of BTM samples were aseptically inoculated into $50 \mathrm{ml}$ (1:10) of Preenrichment media (Buffer Pep-tone Water (BPW), and thoroughly mixed before being incubated at $37{ }^{\circ} \mathrm{C} \pm 1{ }^{\circ} \mathrm{C}$ for $18 \pm 2$ hours. A volume of $0.1 \mathrm{ml}$ was transferred to a tube containing $10 \mathrm{ml}$ of the Rappaport Vassiliadis broth and then incubated at $41.5{ }^{\circ} \mathrm{C}$ for 24 hours. From the enrichment culture, $10 \mu \mathrm{l}$ were inoculated onto the surface of Xylose Lysine Deoxycholate (XLD), Hektoen Enteric and Salmonella Shigella agar plates, then incubated at $37^{\circ} \mathrm{C}$ for 24 hours. Salmonella typical colonies were isolated, and further tested by standard biochemical methods and also serotyped using specific commercial sera. Microscopic identification of salmonella isolates films from suspected purified colonies were prepared, fixed and stained with gram's stain (Cruickshank et al., 1975). Biochemical identification of Salmonella isolates was carried out according to the methods described by ISO6579 (2002). Purified isolates were examined by different biochemical reactions as oxidase, urea hydrolysis, H2S production on TSI, lysine decarboxylation, indole, methyl red test, Voges Proskauer, and citrate utilization tests.

\section{Serotyping of Salmonella}

Salmonella isolates were subjected to serological identification according to the methods described by KauffmanWhite Scheme (Kauffmann, 1973) for determination of somatic $(\mathrm{O})$ and flagellar $(\mathrm{H})$ antigens.

\section{Questionnaire and data collection}

The study questionnaire sheet was designed according to the standard frame prepared by Dufour et al. (2010). The questionnaire sheets included questions related to hygiene of animals, environment and mastitis management. The questions were designed to be as closed as possible to avoid different interpretation between farmers.

\section{Statistical analysis}

All data analysis was carried out using the statistical studies. Association between the occurrence of infection and therefore the potential risk factors were studied using Chi-square $\chi^{2}$ and odds ratio (OR). A database and statistics system for epidemiology on microcomputers were used for performing $\chi 2$ Chi-square tests and odds ratio analysis. Answers to the questionnaire were transferred to Microsoft Excel, and grouped by their categorical response (e.g., Yes, No). Odds ratio was computed according to methods described by Thrusfield (2005). A P-value of $<0.05$ and odds ratio of $>1$ and $\chi 2>3.82$ were regarded a significant association between the response and a category of the count.

\section{Molecular identification of Staphylococcus aureus and Salmonella Typhimurium}

All the identified Staphylococcus aureus and Salmonella positive isolates were examined by PCR for the presence of, Staphylococcus aureus hlg gene and sopB gene of Salmonella. The primers sequence and PCR product sizes are shown in table 1.

\section{DNA extraction}

DNA extraction from samples was done using the QIAamp DNA Mini kit (Qiagen, Germany, GmbH) accord to the manufacturer's instructions. Briefly, $200 \mu \mathrm{l}$ of the sample suspension was used to be incubated with $10 \mu \mathrm{l}$ of proteinase $\mathrm{K}$ and $200 \mu \mathrm{l}$ of lysis buffer at $56^{\circ} \mathrm{C}$ for 10 minutes. After incubation, $200 \mu \mathrm{l}$ of one hundred percent (100\%) ethanol was once introduced to the lysate. The sample was then washed and centrifuged. Nucleic acid was eluted with a hundred (100) $\mu 1$ of elution buffer.

\section{Oligonucleotide primer}

Primers used were provided from Metabion (Germany) which are listed in table 1. 


\section{PCR Design and amplification}

Primers were employed in a $25 \mu \mathrm{l}$ reaction containing $12.5 \mu \mathrm{l}$ of Emerald Amp Max PCR Master Mix (Takara, Japan), $1 \mu 1$ of every primer of 20 pmol concentrations, $4.5 \mu 1$ of water, and $6 \mu 1$ of DNA template. The reaction was done in biosystem 2720 thermal cycler.

\section{Analysis of the PCR products}

$1.5 \%$ agarose gel was used for separating PCR products. For gel analysis, $20 \mu \mathrm{l}$ of the products was loaded in each gel slot. Generuler 100 bp ladder (Fermentas, Thermo, Germany) was used to determine the fragment sizes. The gel was photographed by a gel documentation system (Alpha Innotech, Biometra), and therefore the data was analyzed by using computer software.

Phylogenetics and gene sequence analysis of, sopB gene of Salmonella Typhimurium and hlg Gene of Staphylococcus aureus.

It was performed in Elim biopharmaceuticals, Germany. Amino acids sequence analysis was done using the CLUSTAL W multiple sequence alignment program, version 1.83 of MegAlign module of Lasergene DNAStar software Pairwise, which was designed by Thompson et al. (1994) and Phylogenetic analysis was performed using neighbor joining and in MEGA6 (Tamura et al. 2013).

Table 1. Primer sequences, target genes, amplicon sizes and cycling conditions

\begin{tabular}{|c|c|c|c|c|}
\hline Microorganism & Gene & Sequence $\left(5^{\prime}-3^{\prime}\right)$ & $\begin{array}{r}\text { Amplified } \\
\text { product }\end{array}$ & Reference \\
\hline Salmonella & sopB & $\begin{array}{l}\text { F-5' tcagaagRcgtctaaccactc-3' } \\
\text { R-5'- taccgtcct cat gcacactc-3' }\end{array}$ & $517 \mathrm{bp}$ & Huehnet al. 2010 \\
\hline S. aureus & hlg & $\begin{array}{l}\text { F-5'- GCCAATCCGTTATTAGAAAATGC-3' } \\
\text { F-5'- CCATAGACGTAGCAACGGAT-3' }\end{array}$ & $937 \mathrm{bp}$ & Kumar et al., 2009 \\
\hline
\end{tabular}

S. aureus: Staphylococcus aureus

\section{RESULTS AND DISCUSSION}

Out of a total number of 150 pooled tank milk samples which were collected from 150 dairy cattle farms, 13 locally field isolates were detected and confirmed phenotypically by culturing, gram staining, biochemical and molecular identification to be Staphylococcus aureus in overall herd prevalence of (8.6\%) as shown in table 2. These results nearly agreed with Rysanek et al. (2007) (12.3\% ) and Neder et al. (2011) (11.7\%), but disagreed with Sischo et al. (1993) (45\%), Keefe et al. (1997) ( 70\%), Stephan et al. (2001) (32.4\%), Phuektes et al. (2003) (33\%), Yagoub et al. (2005) Howard (2006) (57.1\%), Miranda-Morales et al. (2008) (30\%) (30\%), USDA (2008) (43\%), Olde Riekerink et al. (2010) (74\%), Katholm et al. (2012) (97\%), Khudor et al. (2012) (28.5\%), Lee et al. (2012) (21.7\%), Amal (2014) (40\%), ElGedawy et al. (2014) (17\%) and Zecconi et al. (2020) (42\%).

Isolation and identification of Salmonella Typhimurium field isolates from bulk tank milk samples revealed that 20 locally field isolates were detected and confirmed phenotypically by culturing, gram staining, biochemical and molecular identification to be Salmonella Typhimurium in overall herd prevalence of (13.3\%) as shown in table 2, this finding agreed with Rohrbach et al. (1992) (8.9\%), O’Donnell (1995) (0.36\%), Steele et al. (1997) (0.17\%), Karns et al. (2005) (11.8\%), Van Kessel et al. (2008) (11\%) and Abo-shama (2013) (14\%) but disagreed with Hassan et al. (2000) (1.5\%), Jayarao and Henning (2001) (6.1\%), Murinda et al. (2002) (2.24\%), Warnick et al. (2003) (1.1\%), Van Kessel et al. (2004) ( 2.6\%), Jayarao et al. (2006) (6\%), Pangloli et al. (2008)(7\%), Addis et al. (2011) (28.6\%), Van Kessel et al. (2011) (48\%), Tajbakhsh et al. (2013) (3.63\%), El-Gedawy et al. (2014) (9\%) and Sonnier et al. (2017) (18\%). Serological identification of the 20 isolates revealed that they were Salmonella Typhimurium. The results of TBPC (cfu/ml) as shown in table 3, revealed that the geometric mean of 150 dairy farms was $3.2 \times 10^{8} \mathrm{cfu} / \mathrm{ml}$.This finding agreed with $\left(1.9 \times 10^{8} \mathrm{cfu} / \mathrm{ml}\right)$ Godefay and Molla (2000), $\left(2.67 \times 10^{8} \mathrm{cfu} / \mathrm{ml}\right)$, Khin Zar Lin (2015), but disagreed with Abdallah (2002) $\left(2.7 \times 10^{7} \mathrm{cfu} / \mathrm{ml}\right)$, Bonfoh (2003) $\left(1.1 \times 10^{7} \mathrm{cfu} / \mathrm{ml}\right)$, Chye et al. $(2004)\left(1.2 \times 10^{6} \mathrm{cfu} / \mathrm{ml}\right)$, Axelsson (2004) $\left(2.4 \times 10^{4} \mathrm{cfu} / \mathrm{ml}\right)$, El-Diasty and El-Kaseh (2009) $\left(6.1 \times 10^{5} \mathrm{cfu} / \mathrm{ml}\right)$, Pantoja et al. (2009) $\left(1.2 \times 10^{4}\right)$, Uddin et al. (2011) $\left(1.28 \times 10^{9} \mathrm{cfu} / \mathrm{ml}\right)$, Hakem et al. (2012) (minimum count $3.7 \times 10^{5}$ and maximum count $4.9 \times 10^{5} \mathrm{cfu} / \mathrm{ml}$ ), Beli 
(2015) $\left(3.89 \times 10^{6} \mathrm{cfu} / \mathrm{ml}\right)$, Meshref (2013), $\left.3.62 \times 10^{7} \pm 1.37 \times 10^{7} \mathrm{cfu} / \mathrm{ml}\right)$ and Tasci $(2011)\left(3.95 \times 10^{6} \mathrm{cfu} / \mathrm{ml}\right)$. Staphylococcus aureus is known as one of the foremost important causes of cattle mastitis, and it causes great economic losses in the dairy industry (Dufour et al., 2012). In term of Staphylococcus aureus count (SAC), the geometric mean value of SAC in present study was $3.7 \times 10^{3} \mathrm{cfu} / \mathrm{ml}$ as shown in table 3. These findings agreed with Stephan et al. (2001) ( $\left.3 \times 10^{3} \mathrm{cfu} / \mathrm{ml}\right)$ but disagreed with Peles et al. (2007) $\left(6.0 \times 10^{3} \mathrm{cfu} / \mathrm{ml}\right)$. The results in table 3 show that the geometric mean of SCCs $/ \mathrm{ml}$ in BTM samples of 150 cattle dairy farms were $556.7 \times 10^{3}$; this result agreed with Erskine et al. (1987) (SCC $700 \times 10^{3}$ cells $\left./ \mathrm{ml}\right)$, Fox et al. (2003) $\left(533 \times 10^{3}\right.$ cells $\left./ \mathrm{ml}\right)$ and Pantoja (2009) $\left(600 \times 10^{3}\right.$ cells $\left./ \mathrm{ml}\right)$, and however disagreed with Desmasures et al. (1997) $\left(176 \times 10^{3}\right.$ cells $\left./ \mathrm{ml}\right)$, Secretaríade Agricultura Ganadería Pescay Alimentos (SAGPyA) (2005) $\left(384 \times 10^{3}\right.$ cells $\left./ \mathrm{ml}\right)$, Rysanek et al. (2007) $\left(240 \times 10^{3}\right.$ cells $\left./ \mathrm{ml}\right)$ in milk without pathogen, $\left(330.8 \times 10^{3}\right.$ cells $\left./ \mathrm{ml}\right)$ with single pathogen and $\left(367.6 \times 10^{3}\right.$ cell $\left./ \mathrm{ml}\right)$ with double pathogens, Vissio et al. $(2008)\left(250 \times 10^{3}\right.$ cells $/ \mathrm{ml}$ ). Bulk tank SCC could be a general indicator of the udder health in a herd, and it was also considered as an indirect index of milk quality (Schukken et al., 2003). Bulk tank SCC (BTSCC) was mainly known as one of the important tools to define the national and international regulative standards that control the hygienic milk production. The national standards for BTSCC differ from < 400,000 cells/ml (EU, Australia, New Zealand and Canada) to < $1,000,000$ cells/ml (Brazil) (USDA, 2013). The USDA introduced a program that permits dairy processors to get an export certificate that confirm farm-level consent with the $(400,000$ cell/ml) limit adopted within the EU (USDA 2011).

Table 2. Point prevalence of Staphylococcus aureus and Salmonella Typhimurium in bulk tank milk in different localities

\begin{tabular}{ccccccccccccccccc}
\hline \multicolumn{10}{c}{ Governorates } \\
\hline & cairo & Giza & Qulobia & Sharkia & Monofia & Alexandria & Behira & Dkhalia & Benisuef & Fayoum & sohag & Aswan & Asuet & total \\
\hline Poulation at nisk & 1520 & 644 & 671 & 729 & 841 & 718 & 284 & 502 & 620 & 618 & 549 & 510 & 461 & 8677 \\
S.aureus & 1 & 1 & 1 & 2 & 2 & 0 & 0 & 3 & 1 & 0 & 1 & 0 & 1 & 13 \\
S.typhimurium & 2 & 1 & 1 & 3 & 3 & 1 & 1 & 4 & 0 & 1 & 1 & 1 & 1 & 20 \\
\hline
\end{tabular}

S. aureus: Staphylococcus aureus: S. Typhimurium: Salmonella Typhimurium

Table 3. Geometric mean value of Standard plate count, Somatic cell count and Staphylococcus aureus in bulk tank milk in different localities

\begin{tabular}{cccc}
\hline Governorates & $\begin{array}{c}\text { Geometric mean of } \\
\text { SPC cfu /ml }\end{array}$ & $\begin{array}{c}\text { Geometric mean of } \\
\text { SCC } \times \mathbf{1 0}^{\mathbf{3}}\end{array}$ & $\begin{array}{c}\text { Geometric mean of } \\
\text { S. aureus } \mathbf{c f u} / \mathbf{m l} \times \mathbf{1 0} \mathbf{3}^{\mathbf{3}}\end{array}$ \\
\hline Cairo & $7.9 \times 10^{8}$ & 455 & 3.2 \\
Giza & $6.3 \times 10^{8}$ & 372 & 4.7 \\
Qulobia & $1.7 \times 10^{7}$ & 438 & 5.7 \\
Sharkia & $2.4 \times 10^{8}$ & 669 & 3.8 \\
Monofia & $6.9 \times 10^{8}$ & 352 & 7.2 \\
Alexandria & $1.7 \times 10^{8}$ & 552 & 3.4 \\
Behira & $1.2 \times 10^{8}$ & 620 & 3.6 \\
Dkahlia & $2.9 \times 10^{7}$ & 559 & 2.1 \\
Benisuef & $9.7 \times 10^{7}$ & 679 & 2.3 \\
Fayoum & $3.7 \times 10^{8}$ & 597 & 3.1 \\
Sohag & $2.4 \times 10^{7}$ & 567 & 4.7 \\
Aswan & $7.2 \times 10^{8}$ & 812 & 778 \\
Asuet & $3.7 \times 10^{8}$ & 556.7 & 3.7 \\
Geometric mean value & $3.2 \times 10^{8}$ & & 3.7 \\
\hline
\end{tabular}

SPC: Standard plate count; SCC: Somatic cell count

As shown in tables 4, 5 and 6 risk factors that were found to be associated with Staphylococcus aureus, Salmonella Typhimurium, SPC and SCC in bulk tank milk samples were Purchasing cattle or heifers as a risk factor has a significant association with Staphylococcus aureus, Salmonella Typhimurium, SPC and SCC in bulk tank milk as shown in table 4

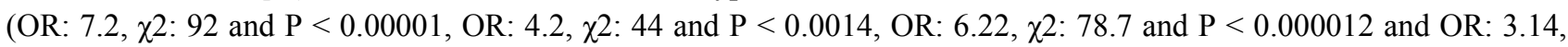
$\chi 2: 23.3$ and $\mathrm{P}<0.001$ respectively). In spite of the actual fact that non lactating heifers have not yet been in connection with the milking equipment, they would still be infected with Staphylococcus aureus (Fox, 2009). Therefore, the purchase of Staphylococcus aureus-positive heifers was considered as one of the foremost vital risk factors for the introduction and spread of Staphylococcus aureus within the herd after they start lactation. The introduction of cattle was previously related to an increased risk of clinical salmonellosis. These animals were also carrier of Salmonella, and should contribute to extend Salmonella infection in the farm. These findings agreed with Nielsen et al. (2007). Cows purchased into the dairy herd were also infected with mastitis pathogens, and were a possible risk to other cows within the herd, and therefore affecting the level of bulk tank milk SCC and SPC. To prevent the introduction of mastitis pathogens when purchasing cows, a balance need is required to be found between minimizing the probability of buying 
an infected cow and maintaining sufficient choice within the population from which to pick replacements (Gunn et al., 2008). Quarantine and test all purchased incoming heifers for contagious mastitis as a risk factor recorded a significant association with Staphylococcus aureus, Salmonella Typhimurium SPC and SCC in bulk tank milk as shown in table 4 (OR: 4.92, $\chi 2$. 24 and $\mathrm{P}<0.00028$, OR.: 3.92, $\chi 2$ : 31.4 and $\mathrm{P}<0.0028$, OR: 4.12, $\chi 2.42 .8$ and $\mathrm{P}<0.00024$ and OR: 3.92 , $\chi 2: 34.4$ and $\mathrm{P}<0.00128$ respectively).

Herds that were not quarantined bought animals which have been generally observed to be positive for Staphylococcus aureus in BTM than herds where quarantine was once applied. Intramammary infections brought by Staphylococcus aureus were usually sub-clinical; thus, Staphylococcus aureus can continue to be unnoticed and disregarded by producers if no testing was done. Moreover, testing newly bought heifers previous to introducing them into the farm would be critical and necessary for forbidding and diminishing the spread of Staphylococcus aureus and retaining the occurrence of recent infections to an occasional degree (DaCosta et al., 2016). Non applying quarantine policy in cattle dairy farms as a risk factor encompassed a significant association with Salmonella prevalence in bulk tank milk. Approximately half of the dairy herds purchased animals, and about half of the buying herds did not quarantine incoming animals (Nöremark et al., 2016). If purchase could not be avoided, quarantine is often unable to reduce the risks (Vanselow et al., 2007). Not applying fly control as a risk factor as shown in table 4 was clearly related to Staphylococcus aureus, Salmonella Typhimurium, SPC and SCC in bulk tank milk (OR:3.2, $\chi 2.22$ and P $<0.0016$, OR: 2.29, $\chi 2$ : 25.4 and $\mathrm{P}<0.0029$, OR: 4.2, $\chi 2.47 .2$ and $\mathrm{P}<0.00032$ and $\mathrm{OR}: 3.2, \chi 2.39$ and $\mathrm{P}<0.006$ respectively).

Flies played a vital role in the transmission of Staphylococcus aureus between infected and uninfected heifers, and not applying fly control in cattle dairy farms was considered one of the most important risk factors for heifer's intramammary infection caused by Staphylococcus aureus (Capurro et al., 2010; Piepers et al., 2011; Anderson et al., 2012). Presence of biting flies that purpose teat lesions was related to a high level of Staphylococcus aureus mastitis suggesting that fly control should be included during a mastitis management plan (Ryman et al., 2013). Flies carry a variety of mastitis-causing organisms that may colonize in teat lesions, and affect SCC and SPC in bulk tank milk. One among the foremost probable suggested causes for the increased incidence of mastitis, and also the increased bulk tank SCC and SPC level was that the irritation of udders by flies, and also the spreading of microorganisms by these insects. Another report showed that presence of biting flies causing teat lesions was related to a high level of mastitis, and suggested that fly control should be included during a mastitis management plan (Ryman et al., 2013). Heifers from herds using fly control had a lower prevalence of mastitis in comparison with herds where no fly control was applied (Nickerson et al., 1995). Heavy fly infestation was known as one of the foremost important risk factors for salmonella in dairy cattle farms.Flies that feed on cattle manure played a critical role in Salmonella shedding in dairy farm environments (Holt et al., 2007; Thomson et al., 2017). Not milking cows with a high SCC/CM grouped separately as shown in table 4, were significantly related to Staphylococcus aureus, SPC and SCC in bulk tank milk (OR :2.72, $\chi 2: 17$ and P<0.0058, OR.: 1.73, $\chi 2: 12.7$ and $\mathrm{P}<0.03$, OR: 5.93, $\chi 2: 46.9$ and $\mathrm{P}<0.00023$, OR: 4.73, $\chi 2 ; 42.8$ and $\mathrm{P}<0.00021$ respectively) and not milking all incoming cattle separately or last as shown in table 4 (OR: 6.34, $\chi 2: 62$ and $\mathrm{P}<0.00002, \mathrm{OR}: 3.22$, $\chi 2$ : 42.5 and $\mathrm{P}<0.0021$ and OR: $4.34, \chi 2: 42.8$ and $\mathrm{P}<0.00045$ respectively) as shown in table 4.

It is still preferable to milk cows with a high SCC/CM last and grouping separately (Barnouin et al., 2004). Cows in herds that did not milk cows with mastitis last were significantly more likely to have mastitis than those who did that. Failure to milk cows with mastitis last played a vital role in spreading of mastitis pathogens between cows by milker's hands leading to contagious mastitis, and also played a great role in affecting bulk tank SPC and SCC (FAO, 2014). High SCC cows and clinical mastitis cases should be milked last, employing a specific milking unit for these cows or rinsing, cleaning, or disinfecting the unit after these cows are milked, and before first-lactation cows are milked were significantly related to low bulk tank SCC (Dufour et al., 2011). Milking cows with mastitis in no specific order was another practice that significantly affected the Staphylococcus aureus presence in BTM. Riekerink et al. (2006) also observed lower incidence rates for Staphylococcus aureus in BTM belonging to herds with mastitis-affected cows milked separately from healthy cows. Teat cups were known as the foremost bacterial transmission tool (Benić et al., 2012), and therefore, cows affected with mastitis should be milked separately or after healthy animals (NMC, 2001; Zecconi, 2006; Arnold and Bewley, 2011; Middleton 2013). Not cleaning and disinfecting equipment and milking unit after milk infected cattle as a risk factor for Staphylococcus aureus, Salmonella Typhimurium SPC and SCC in bulk tank milk (OR: 6.98, $\chi 2.75$ and $\mathrm{P}<0.000016$, OR: 2.78, $\chi 2.29 .4$ and $\mathrm{P}<0.016$, OR: 5.68, $\chi 2: 59.4$ and $\mathrm{P}<0.000012$ and $\mathrm{OR}$ : 4.72, $\chi 2$ : 55.2 and $\mathrm{P}<0.00013$ respectively) as shown in table 4. Poorly cleaned and sanitized milking utensils were regarded as a very important source of the many microorganisms in bulk tank milk. Cleaning and sanitation of the milking equipment may well be considered as a critical point in the milking procedure, because a cleaning failure could influence the level of bacterial contamination of bulk tank milk (Bava et al., 2009). Cleaning and sanitation of the milking equipment were also identified as a risk factor related to high bacterial counts (Elmoselmany et al., 2009a; Jayarao et al., 2004). 


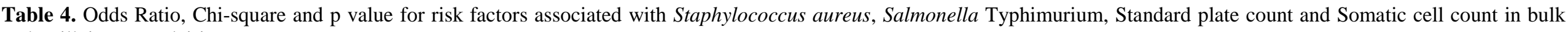
tank milk in Egypt dairies

\begin{tabular}{|c|c|c|c|c|c|c|c|c|c|c|c|c|}
\hline \multirow{2}{*}{ Risk factors } & \multicolumn{3}{|c|}{ S.aureus } & \multicolumn{3}{|c|}{ S. Typhimurium } & \multicolumn{3}{|c|}{ SPC } & \multicolumn{3}{|c|}{ SCC } \\
\hline & OR & $\chi^{2}$ & P value & OR & $\chi^{2}$ & $P$ value & OR & $\chi^{2}$ & P value & OR & $\chi^{2}$ & P value \\
\hline Purchasing cattle or heifers & 7.2 & 92 & $<0.00001$ & 4.2 & 44 & $<0.0014$ & 6.22 & 78.7 & $\mathrm{P}<0.000012$ & 3.14 & 23.3 & $\mathrm{P}<0.001$ \\
\hline $\begin{array}{l}\text { Not quarantining and Test all purchased incoming heifers } \\
\text { for contagious mastitis }\end{array}$ & 4.92 & 24 & $<0.00028$ & 3.92 & 31.4 & $<0.0028$ & 4.12 & 42.8 & $\mathrm{P}<0.00024$ & 3.92 & 34.4 & $\mathrm{P}<0.00128$ \\
\hline missed fly control & 3.2 & 22 & $<0.0016$ & 2.29 & 25.4 & 0.0029 & 4.2 & 47.2 & $\mathrm{P}<0.00032$ & 3.2 & 39 & $\mathrm{P}<0.006$ \\
\hline $\begin{array}{l}\text { Not milking Cows with a high SCC/CM grouped } \\
\text { separately and milked last at each milking }\end{array}$ & 2.72 & 17 & $<0.0058$ & 1.73 & 12.7 & $<0.03$ & 5.93 & 56.9 & $\mathrm{P}<0.00023$ & 4.73 & 42.8 & $\mathrm{P}<0.00021$ \\
\hline Not milking all incoming cattle separately or last & 6.34 & 62 & $<0.00002$ & 2.12 & 22.3 & $<0.023$ & 3.22 & 42.5 & $\mathrm{P}<0.0021$ & 4.34 & 42.8 & $\mathrm{P}<0.00045$ \\
\hline $\begin{array}{l}\text { Not cleaning and disinfect equipments and milking unit } \\
\text { after milk infected cattle }\end{array}$ & 6.98 & 75 & $<0.000016$ & 2.78 & 29.4 & $<0.016$ & 5.68 & 59.4 & $\mathrm{P}<0.000012$ & 4.72 & 55.2 & $\mathrm{P}<0.00013$ \\
\hline $\begin{array}{l}\text { 7- Sanitary condition of the Barn, access alleys and } \\
\text { Cubicle passages }\end{array}$ & 2.72 & 20 & $<0.014$ & 3.22 & 30.5 & $<0.002$ & 3.12 & 32.5 & $\mathrm{P}<0.0014$ & 2.82 & 27.5 & $\mathrm{P}<0.001$ \\
\hline $\begin{array}{l}\text { Not using Separate cleaned and sanitized calving paddocks } \\
\text { or pens for cows and heifers }\end{array}$ & 2.34 & 16 & $<0.028$ & 2.5 & 17.5 & $<0.013$ & 4.6 & 47.5 & $\mathrm{P}<0.00023$ & 3.16 & 37.6 & $\mathrm{P}<0.0013$ \\
\hline Not housing pregnant heifers with dry cows & 4.35 & 32 & $<0.00028$ & 3.15 & 27.2 & $<0.0018$ & 2.25 & 22.3 & $\mathrm{P}<0.028$ & 2.21 & 20.5 & $\mathrm{P}<0.024$ \\
\hline Herds don't practice checking SCC records & 4.27 & 59 & $<0.000012$ & 2.47 & 19.4 & $<0.0032$ & 5.12 & 79.1 & $\mathrm{P}<0.000002$ & 7.23 & 82 & $\mathrm{P}<0.00000012$ \\
\hline
\end{tabular}

OR: odds ratio, $\chi 2$ : chi square, SPC: Standard plate count, SCC: Somatic cell count, $p$ value: probaplity value

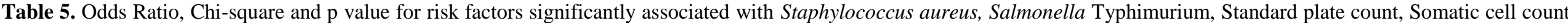
in bulk tank milk in Egypt dairies

\begin{tabular}{|c|c|c|c|c|c|c|c|c|c|c|c|c|}
\hline \multirow{2}{*}{ Risk factors } & \multicolumn{3}{|c|}{ S.aureus } & \multicolumn{3}{|c|}{ S. Typhimurium } & \multicolumn{3}{|c|}{ SPC } & \multicolumn{3}{|c|}{ SCC } \\
\hline & OR & $\chi^{2}$ & P value & OR & $\chi^{2}$ & P value & OR & $\chi^{2}$ & P value & OR & $\chi^{2}$ & P value \\
\hline Cleanliness of the cows (udder and teats) & 2.65 & 19 & $<0.023$ & 4.25 & 49 & $<0.00023$ & 5.15 & 69.7 & $<0.000001$ & 4.21 & 45.9 & $<0.0012$ \\
\hline Muddy bedding materials & 2.25 & 16 & $<0.013$ & 3.15 & 36 & $<0.00015$ & 5 & 66 & $<0.000023$ & 6.5 & 86 & $<0.0000003$ \\
\hline Storage manure indoor & 3.27 & 59 & $<0.00123$ & 4.17 & 62.7 & $<0.00002$ & 6.21 & 89.7 & $<0.000013$ & 2.17 & 29.1 & $<0.0021$ \\
\hline Herd size & 3 & 39 & $<0.0003$ & 4.21 & 49 & $<0.00001$ & 3.2 & 37 & $<0.0003$ & 2.2 & 18.4 & $<0.013$ \\
\hline Not $\mathrm{t}$ applying pre and post-milking teat dipping & 2.79 & 16 & $<0.026$ & 1.87 & 17.5 & $<0.012$ & 3.69 & 31.4 & $<0.00013$ & 2.69 & 21.4 & $<0.0023$ \\
\hline $\begin{array}{l}\text { Not stripping milk regularly into strip cup to detect } \\
\text { mastitis }\end{array}$ & 2.27 & 19 & $<0.015$ & 1.37 & 9.2 & $<0.04$ & 2.37 & 29.5 & $<0.001$ & 6.2 & 78 & $<0.0000001$ \\
\hline Milking wet teats & 2.42 & 24 & $<0.0021$ & 2.27 & 22 & $<0.0021$ & 5.1 & 72 & $<0.000002$ & 7.1 & 92 & $<0.0000001$ \\
\hline $\begin{array}{l}\text { Not using single paper towels or suitable woven cloths for } \\
\text { teats drying }\end{array}$ & 2.58 & 18 & $<0.013$ & 2.78 & 15 & $<0.03$ & 5.58 & 67 & $<0.00004$ & 7.4 & 98 & $<0.0000013$ \\
\hline $\begin{array}{l}\text { Not replacing and sanitize teat cup Liners according to } \\
\text { manufactures instructions }\end{array}$ & 5.79 & 55 & $<0.0006$ & 2.9 & 20.82 & $<0.003$ & 6.26 & 86.4 & $<0.00037$ & 6.79 & 76.9 & $<0.0000032$ \\
\hline $\begin{array}{l}\text { Not testing and service milking machine every } 6 \text { months } \\
\text { or annually }\end{array}$ & 6.24 & 45 & $<0.0004$ & 4.12 & 41.2 & $<0.0002$ & 5.26 & 68.2 & $<0.000001$ & 4.24 & 48.9 & $<0.00002$ \\
\hline Not Wearing latex Gloves & 2.32 & 18.9 & $<0.038$ & 7.1 & 90 & $<0.0000003$ & 7.1 & 90 & $<0.0000003$ & 7.4 & 93 & $<0.000000123$ \\
\hline
\end{tabular}

OR: odds ratio, $\chi 2$ : chi square, SPC: Standard plate count. SCC: Somatic cell count. $p$ value: probaplity value 


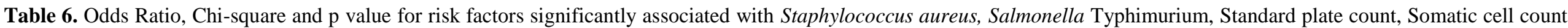
in bulk tank milk in Egypt dairies

\begin{tabular}{|c|c|c|c|c|c|c|c|c|c|c|c|c|}
\hline \multirow{2}{*}{ Risk factors } & \multicolumn{3}{|c|}{ S.aureus } & \multicolumn{3}{|c|}{$S$. Typhimurium } & \multicolumn{3}{|c|}{ SPC } & \multicolumn{3}{|c|}{ SCC } \\
\hline & OR & $\chi^{2}$ & $P$ value & OR & $\chi^{2}$ & $P$ value & OR & $\chi^{2}$ & $P$ value & OR & $\chi^{2}$ & $P$ value \\
\hline $\begin{array}{l}\text { Not washing automatic Clusters with hot disinfectant } \\
\text { after milking a cow with CM or a high SCC }\end{array}$ & 2.43 & 18 & $<0.024$ & 2.12 & 15.7 & $<0.021$ & 4.23 & 48 & $<0.00012$ & 5 & 68.7 & $<0.00000024$ \\
\hline Not applying Back flushing & 5.98 & 59 & $<0.00001$ & 3.28 & 39.7 & $<0.0012$ & 7.28 & 98.4 & $<0.0000021$ & 6.12 & 88.2 & $<0.000001$ \\
\hline Dirty Bulk tank surface & 7.5 & 85 & $<0.000002$ & 5.23 & 68.2 & $<0.0000001$ & 6.7 & 88.3 & $<0.000003$ & 7.2 & 95.3 & $<0.0000003$ \\
\hline Claw pieces don't thoroughly brushed after each milking & 3.5 & 41 & $<0.0001$ & 4.2 & 58 & $<0.000002$ & 6.7 & 78 & $<0.0000001$ & 7 & 93 & $<0.0000002$ \\
\hline $\begin{array}{l}\text { Gaskets and milk valves don't removed cleaned and } \\
\text { brushed daily }\end{array}$ & 5.7 & 75 & $<0.000001$ & 5.2 & 72 & $<0.000001$ & 6 & 82 & $<0.0000023$ & 7 & 93 & $<0.00000004$ \\
\hline Specific cleaning and sanitary program to milk pipelines & 4.5 & 45 & $<0.000021$ & 4.7 & 42 & $<0.0001$ & 5.4 & 62 & $<0.000023$ & 6.8 & 73 & $<0.000005$ \\
\hline $\begin{array}{l}\text { Not cleaning inflation and all other rubber plastic like } \\
\text { parts and free from cracks }\end{array}$ & 3.5 & 35 & $<0.0021$ & 3.7 & 32 & $<0.001$ & 4.4 & 62 & $<0.0003$ & 5 & 53 & $<0.00002$ \\
\hline Summer season & 3.21 & 39 & $<0.00012$ & 2.15 & 19.7 & $<0.02$ & 4.24 & 42.7 & $<0.00014$ & 3.27 & 47.8 & $<0.0002$ \\
\hline Region variation & 2.31 & 19 & $<0.0014$ & 2.46 & 20.7 & $<0.002$ & 3.24 & 41.4 & $<0.0012$ & 2.17 & 27.8 & $<0.0031$ \\
\hline
\end{tabular}

OR: Odds Ratio, $\chi 2$ : Chi Square, SPC: Standard Plate Count, SCC: Somatic Cell Count, $p$ value: probability value 
Milk residues left on the milking equipment contact surface; support the growth of a variety of microorganisms (Murphy and Boor, 2007: Holm et al., 2004). The main aim of sanitizing is to kill residual microorganisms existing on these surfaces immediately prior to milking. Inadequate or improper cleaning and sanitizing permitted the bacteria to remain on the equipment's surfaces, and to grow and multiply these results in elevated count of Staphylococcus aureus, Salmonella Typhimurium, SPC and SCC in bulk tank milk. Satisfactory parlor sanitization and disinfection were very important and essential after each and every milking to help and assist to control the bulk tank total bacterial counts, and to limit the risk of cross infection of mastitis pathogens among cows from contaminated milking equipment (Ian ohnstad, 2013). Not being replaced and sanitized the teat cup liners according to manufactures instructions were significantly associated with Staphylococcus aureus, Salmonella Typhimurium, SPC and SCC in bulk tank (OR: 5.79, $\chi 2: 55$ and P < 0.0006, OR: 2.9, $\chi 2$ : 20.82 and $\mathrm{P}<0.003$, OR: 6.26, $\chi 2: 86.4$ and $\mathrm{P}<0.00037$ and OR: 6.79, $\chi 2: 76.9$ and $\mathrm{P}<0.0000032$, respectively) as shown in table 4 .

The teat cup liner is that the only piece of the milking machine that comes into direct contact with the cow. Worn and rough liners are difficult to be cleaned, and will harbor mastitis bacteria, and also, they affect significantly on the bulk tank SPC and SCC level (Roger Blowey and Peter Edmondson, 2010). The milking equipment consists mainly of various rubber parts. Among these rubber parts, the foremost important part could be a teat cup liner which provided direct contact force to teat tissue. Properties of teat cup liners directly affected the technical and technological process of milking, udder health condition and quality of obtained milk, and seriously was that the finding that cracks on the inner surface of teat cup liners were increasing proportionally with exposition time within the primary production, and that they were a source of pathogenic microorganisms (Gálik et al., 2015). The rubbers parts of milking equipment were taken into an account of one of the foremost potential sources of milk contamination (Krzyś et al., 2011). Sanitary condition of the barn, access alleys and cubicle passages as a risk factor was significantly associated with Staphylococcus aureus, Salmonella Typhimurium, SPC and SCC in bulk tank (OR: 2.72, $\chi 2: 20$ and P $<0.014$, OR: 3.22, $\chi 2.30 .5$ and $\mathrm{P}<0.002$, OR. 3.12, $\chi 2.32 .5$ and $\mathrm{P}<0.0014$ and OR. 2.82, $\chi 2.27 .5$ and $\mathrm{P}<0.001$ respectively) as shown in table 4.

Facility hygiene included the cleanliness of the barn, access alleys and milking parlor, thought as an essential and vital part of hygienic milk production and quality control program. Cleaning and renewing the bedding of the cubicles and yards should ideally be performed during milking, so as cows exit from the parlor, they were able to walk back along clean passage ways, pasted fresh food, and then lay down in clean cubicles (Blowey and Edmondson, 2010). This kept the teats as clean as possible during the primary critical 20 to 30 minutes after milking, when the cow was more susceptible to mastitis, because the teat sphincter did not fully close (Blowey and Edmondson, 2010). It also reduced the quantity of feces carried back on to the cubicle beds by soiled feet. Clean farms and houses were strongly related to lower SPC and SCS (Chassagne et al., 2005). Implementing and maintaining few and straight forward hygienic practices in terms of barn cleaning can significantly improve microbiological quality of cow milk, and reduce somatic cell count (Zucali et al., 2011). Surveys were performed to determine relations among measures associated with facility hygiene and microbial counts in bulk tank milk. A correlation between the dirtiness of the access alley to the milking parlor, and therefore the total bacterial count in bulk tank milk were reported by Christiansson et al. (1999). A powerful association was observed among increased bacterial content in bulk tank milk and cleanliness score of the farm facilities and milking cows (Elmoslemany et al. 2009a; Zucali et al. 2011). There was a distinct association amongst cleanliness of housing areas, and therefore the rate of clinical mastitis and high somatic cell counts in bulk tank milk were also established (Barkema et al., 1998). The poor hygienic condition of the farm facilities was a striking feature, which was along with inefficient sanitation of the facilities favored the proliferation and dissemination of salmonella among animals and environmental contamination. Proper and regular cleaning and ordinary barn disinfection routines in dairy cattle farms played an important role in controlling salmonellosis in dairy cattle farms. These agreed with Tarazi and Abo-shehada (2015). Sanitation and hygienic measures of dairy cattle farms had a great impact on reduction and lowering Staphylococcus aureus levels in dairy cattle farms (Sartori et al., 2017). Not testing and servicing the milking machine every 6 months or annually were considered as risk factor for Staphylococcus aureus, Salmonella Typhimurium, SPC and SCC in bulk tank milk (OR: 6.24, $\chi 2: 45$ and $\mathrm{P}<0.0004$, OR: 4.12, $\chi 2: 41.2$ and $\mathrm{P}<0.0002$, OR. 5.26, $\chi 2: 68.2$ and $\mathrm{P}<0.000001$ and OR: 4.24, $\chi 2: 48.9$ and $\mathrm{P}<0.00002$ respectively) as shown in table 4.

There were a wide variety of milking machine efficiency faults. These usually resulted from gradual changes in milking machine performance due to continued use, wear and age. The efficiency and performance of milking machine components affected mastitis incidence, mainly by their effects on the new mastitis infection rate. It is very important and critical that milking machines should be tested by a qualified technician or adviser on a regular basis. Regular testing, service and maintenance of milking machine is extremely necessary to maintain proper mechanical performance, to boost the speed and completeness of milking, and to improve bulk tank SPC and SCC level. These findings agreed with Rodrigues et al. (2005). Milking machines without proper maintenance in general became the main reason of high bacteriological counts in milk (Reinemann et al., 1997; Murphy and Boor, 2000). The milking parlor should be kept clean, and proper performance of the milking system should be ensured by having the system inspected at the minimum 
annually (Dufour et al., 2011). Not applying pre and post-milking teat dipping was as a risk factor for Staphylococcus aureus, Salmonella Typhimurium, SPC and SCC in bulk tank milk (OR:2.79, $\chi 2$ : 16 and P < 0.026, OR: 1.87, $\chi 2$ : 17.5 and $\mathrm{P}<0.012$, OR: $3.69, \chi 2: 31.4$ and $\mathrm{P}<0.00013$ and $\mathrm{OR}: 2.69, \chi 2: 21.4$ and $\mathrm{P}<0.0023$, respectively) as shown in table 4 .

The practice of pre- and post-milking teat dipping was one of the main important and critical components for controlling and preventing of mastitis and a control program in a dairy herd. Teat dipping is now a widely and universally accepted practice for reducing the bacterial population around the teat end, thus for reducing the risk of mastitis. The proper application of an accurate post-milking teat disinfection product to cow teats after milking could be the most significant and important task. After milking, bacteria multiply on the teat skin, and will extend into the teat canal. If the entire surface of every teat is disinfected immediately after milking, this establishment of bacteria would be minimized. Teat disinfection is on was in every of the foremost effective sub-clinical and clinical mastitis control measures available. Failure to cover the entire teat of each cow at every milking was that the most typical error in teat disinfection. Teat dipping was very important in reduction of Staphylococcus aureus teat colonization (Da Costa et al., 2014). Number of the advantages of those practices was related to reducing and lowering of the microbial contamination of the teats (Zucali et al., 2011). Post-milking teat sanitization reduced BTSCC, and was clearly and significantly related to individual-cow somatic cell count (ICSCC) (Tadich et al., 2003; Barnouin et al., 2004a; Dufour et al., 2011). Dipping all teats after each milking had the greatest effect on reduction of bulk milk somatic cell counts, and it increased milk yields more than any other milking practice. Pre-milking teat dipping played an important and significant role in reduction of BTSCC. Proper and correct teat-end disinfection before the cluster attached can reduce teat surface bacteria by $75 \%$ (Reinemann et al., 2008), and was effective in preventing and controlling mastitis caused by environmental and contagious pathogens (Ruegg and Dohoo, 1997). Not stripping milk regularly into strip cup to detect mastitis as a risk factor was significantly associated with Staphylococcus aureus, SPC and SCC in bulk tamk milk (OR: 2.27, $\chi 2$ : 19 and P $<0.015$, OR: 1.37, $\chi 2$ : 9.2 and $\mathrm{P}<0.04$ and OR.:2.37, $\chi 2: 29.5$ and $\mathrm{P}<0.001, \mathrm{OR}: 6.2, \chi 2: 78$ and $\mathrm{P}<0.0000001$ respectively) as shown in table 4 .

In the herds in which fore-milking was practiced using the fore-stripper, lower SCC was observed. These findings agreed with Skrzypek (2002), Wagner and Ruegg (2002) and Down (2016). Fore-milking and therefore the visual appraisal of fore-milk were widely recommended to be performed before each milking as they eased accurate identification of the clinical mastitis in individual quarters and immediate treatment of affected cows, like wise as their milking using separate equipment. Fore-stripping was extremely useful for checking milk quality, and had a great role in milk let down. Not utilizing separate cleaned and sanitized calving paddocks or pens for cows and heifers was significantly associated with Staphylococcus aureus, Salmonella Typhimurium, SPC and SCC in bulk tank milk (OR: 2.34, $\chi 2: 16$ and $\mathrm{P}<0.028$, OR: 2.5, $\chi 2 ; 17.5$ and $\mathrm{P}<0.013$, OR: 4.6, $\chi 2: 47.5$ and $\mathrm{P}<0.00023$ and $\mathrm{OR}: 3.16, \chi 2: 37.6$ and $\mathrm{P}<0.0013$, respectively) as shown in table 4 . The present study provided evidence for the importance of using separate calving pens for cows and heifers, and its disinfection for the successful control of Staphylococcus aureus, Salmonella Typhimurium, SPC and SCC in bulk tank milk. the current results agreed with Down (2016), Barnouin et al. (2004) and O'Reilly et al. (2006). This effect may could be due to a reduction in pathogen exposure, but additionally may reflect, the negative impact of cross-suckling calves indirectly which was related to mastitis incidence (Green et al., 2007). Cows are susceptible to infection before calving because their natural defense mechanisms are low, new infections occur, and subclinical infections which persisted through the dry period may flare into clinical cases (Down 2016). Housing pregnant heifers with dry cows as a risk factor was significantly associated with Staphylococcus aureus, Salmonella Typhimurium, SPC and SCC in bulk tank (OR:4.35, $\chi 2.32$ and $\mathrm{P}<0.00028, \mathrm{OR}: 3.15, \chi 2.27 .2$ and $\mathrm{P}<0.0018, \mathrm{OR}$ : 2.2, $\chi 2: 22.3$ and $\mathrm{P}<0.028$ and $\mathrm{OR}: 2.21, \chi 2: 20.5$ and $\mathrm{P}<0.024$, respectively) as shown in table 4 .

These findings agreed with Down (2016). Understanding the mastitis risk factors for dry cows and heifers could also be considered as a critical and vital step to reduce mastitis prevalence. At the time of dry off, cows are not given the protection from post-dip, and their udders are not observed closely for signs of infection. All of those factors contribute and play a key role in elevation the bulk tank level of microbial count and SCC. Herds don't keep SCC records was believed as a risk factor for Staphylococcus aureus, Salmonella Typhimurium, SPC and SCC in bulk tank milk (OR:

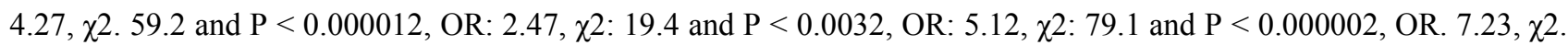
82 and $\mathrm{P}<0.00000012$, respectively) as shown in table 4 . The lowest SCC observed in the herds that was practiced milk recording was possibly because of increased farmer knowledge on individual cows, and its importance as a factor associated with SCC. These results agreed with Hutton et al. (1990) and Down (2016). If dairy producers do not record milk, then it would be difficult to identify cows with constantly elevated SCC, thereby may cause an increasing in the overall bulk SCC. Barkema et al. (1999) found that farmers of herds with a low bulk tank SCC kept better records and were extra acquainted and familiar with every cow in their herds. Milking wet teats was a risk factor for Staphylococcus aureus, Salmonella Typhimurium, SPC and SCC in bulk tank milk (OR: 2.42, $\chi 2.24$ and P < 0.0021, OR: 2.27, $\chi 2$ : 22 and $\mathrm{P}<0.0021$, OR: 5.1, $\chi: 72$ and $\mathrm{P}<0.000002$, OR: 7.1, $\chi 2.92$ and $\mathrm{P}<0.0000001$, respectively) as shown in table 5 . 
Milking wet teats is unacceptable, both for risk of mastitis and elevation of bulk tank SCC and all over total microbial count and subsequent milk quality issues. Water plays an important and vital role in fostering mastitis pathogens on the udder and teats. Water laden with bacteria on udder and teat surfaces can enter teat cup liners, and may increase bacterial contamination of milk, and also increase mastitis incidence, and then subsequently elevate bulk tank SCC (Blowey and Edmondson, 2010). Not using single paper towels or suitable woven cloths for teats' drying was believed as a risk factor for Staphylococcus aureus, Salmonella Typhimurium, SPC and SCC in bulk tank milk (OR: 2.58, $\chi 2.18$ and $\mathrm{P}<0.013$, OR. 2.78, $\chi 2.15$ and $\mathrm{P}<0.03$, OR. 5.58, $\chi 2.67$ and $\mathrm{P}<0.00004$ and OR: $7.4, \chi^{2} .98$ and $\mathrm{P}<0.0000013$, respectively) as shown in table 5 .

Effective drying had a great impact on the level of SCC in bulk tank milk, and was achieved by using single paper towels or suitable woven cloths. Each cloth must only be used for one cow per milking. Cloths should then be placed in disinfectant solution, washed before the next milking (Blowey and Edmondson, 2010). Not wearing latex gloves was taken as risk factor for Staphylococcus aureus, Salmonella Typhimurium, SPC and SCC in bulk tank milk (OR: 2.92, $\chi 2: 20.4$ and $\mathrm{P}<0.028$, OR. 2.32, $\chi 2.18 .9$ and $\mathrm{P}<0.038$, OR: 7.1, $\chi 2.90$ and $\mathrm{P}<0.0000003$, OR: 7.4, $\chi 2.93$ and $\mathrm{P}<$ 0.000000123 , respectively) as shown in table 5 .

These findings agreed with Bach et al. (2008) and Signorin et al. (2008). The milker can spread contagious mastitis as he handles each cow. The use of gloves was one of the foremost important factors to prevent mastitis caused by Staphylococcus aureus agents in dairy cows (Petersson-Wolfe et al., 2010; Arnold and Bewley, 2011), and was included in the National Mastitis Council mastitis control plan (NMC 2001). The operator's hands can be a mean for bacterial dissemination, and gloves have a great role in reducing total bacteria count in bulk tank milk (Nickerson, 2014); Wearing latex gloves decreased Staphylococcus aureus prevalence, and incidence in BTM (Dufour et al., 2012). Not washing automatic clusters with hot disinfectant after milking a cow with CM or a high SCC was considered as a risk factor for Staphylococcus aureus, Salmonella Typhimurium, SPC and SCC in bulk tank milk (OR: 2.43, $\chi 2: 18$ and P $<0.024$, OR: 2.12, $\chi 2.15 .7$ and $\mathrm{P}<0.021$, OR.:4.23, $\chi 2$ : 48 and $\mathrm{P}<0.00012$, OR: 5, $\chi 2: 68.7$ and $\mathrm{P}<0.00000024$, respectively) as shown in table 5 .

These findings agreed with Wenz et al. (2007) and Down (2016). At the end of milking, a small quantity of milk is held inside the mouth piece of the line. When the cluster is connected to the next cow, the milk from the previous cow will run down the inner part of the liner, and contaminate the teat of the next cow to which is milking. This represented a risk of infection transferring (Blowey and Edmondson, 2010). Teat contamination occurred via the cluster which was previously contaminated during milking of an infected cow was considered as a great vital point for cross-contamination between cows. Clusters are a usual origin and source of bacteria for dairy cows. Infected cow (clinical case or subclinical case with excessive bacterial numbers) had the potential to infect the subsequent 5 to 6 cows milked on that cluster. It was not ideal to wash the cluster (either back-flushing or through-flushing) with cold water. Not applying back-flushing as a risk factor significantly associated with Staphylococcus aureus, Salmonella typhimurium, SPC and SCC in bulk tank (OR :5.98, $\chi 2.59$ and $\mathrm{P}<0.00001$, OR. 3.28, $\chi 2.39 .7$ and $\mathrm{P}<0.0012$, OR. 7.28, $\chi 2.98 .4$ and $\mathrm{P}<$ 0.0000021 , OR. 6.12, $\chi 2.88 .2$ and $\mathrm{P}<0.000001$, respectively) as shown in table 6. Dirty bulk tank surface as a risk factor was significantly associated with Staphylococcus aureus, Salmonella Typhimurium, SPC and SCC in bulk tank (OR :7.5, $\chi 2$ : 85 and $\mathrm{P}<0.000002$, OR: 5.23, $\chi 2$ : 68.2 and $\mathrm{P}<0.0000001, \mathrm{OR}: 6.7, \chi 2: 88.3$ and $\mathrm{P}<0.000003$ and $\mathrm{OR}$ : 7.2, $\chi 2$ : 95.3 and $\mathrm{P}<0.0000003$, respectively) as shown in table 6.

Claw pieces were not thoroughly brushed after each milking considered as a risk factor was significantly associated with Staphylococcus aureus, Salmonella Typhimurium, SPC and SCC in bulk tank (OR: 3.5, $\chi 2$ : 41 and P<0.0001, OR. 4.2, $\chi 2$ : 58 and $\mathrm{P}<0.000002$, OR: 6.7, $\chi 2: 78$ and $\mathrm{P}<0.0000001$ and $\mathrm{OR} .7, \chi 2.93$ and $\mathrm{P}<0.0000002$, respectively) as shown in table 6. Gaskets and milk valves were not removed cleaned and brushed daily, it as a risk factor was significantly associated with Staphylococcus aureus, Salmonella Typhimurium, SPC and SCC in bulk tank (OR: 5.7, $\chi 2 .: 75$ and $\mathrm{P}<0.000001$, OR: 5.2, $\chi 2: 72$ and $\mathrm{P}<0.000001$, OR: 6, $\chi 2: 82$ and $\mathrm{P}<0.0000023$ and OR. 7, $\chi 2.93$ and $\mathrm{P}<$ 0.00000004 , respectively) as shown in table 6. Specific cleaning and sanitary program to milk pipelines as a risk factor was significantly associated with Staphylococcus aureus, Salmonella Typhimurium, SPC and SCC in bulk tank (OR: 4.5, $\chi 2: 45$ and $\mathrm{P}<0.000021, \mathrm{OR}: 4.7, \chi 2: 42$ and $\mathrm{P}<0.0001$, OR: 5.4, $\chi 2: 62$ and $\mathrm{P}<0.000023$ and $\mathrm{OR}: 6.8, \chi 2: 73$ and $\mathrm{P}<$ 0.000005 , respectively) as shown in table 6. Not cleaning inflation and all other rubber plastic like parts and free from cracks as a risk factor were significantly associated with Staphylococcus aureus, Salmonella Typhimurium, SPC and SCC in bulk tank (OR: 3.5, $\chi 2.35$ and $\mathrm{P}<0.0021$, OR: 3.7, $\chi 2: 32$ and $\mathrm{P}<0.001$, OR. 4.4, $\chi 2: 62$ and $\mathrm{P}<0.0003$ and OR.; 5, $\chi 2: 53$ and $\mathrm{P}<0.00002$, respectively) as shown in table 6 .

Back-flushing units will help to get rid of both environmental and contagious bacteria, and this may only be of benefit on reducing the bulk tank SCC and SPC level (Blowey and Edmondson, 2010). All internal parts of the tank that can come into contact with milk must be cleaned and disinfected. It was very necessary that the worker checks the internal parts of the tank to be cleaned and disinfected before milking (Blowey and Edmondson, 2010). Dirty bulk tanks played a definite role, and have a great impact on bulk tank SCC and total bacterial level. It is very important to regularly 
check and replace the rubber parts. The rubber plastic like parts was thought to be one of the foremost important sources for bulk tank microbial contamination. Therefore, most standard cleaning program should be beginning with hot water at $35^{\circ} \mathrm{C}$ to $40^{\circ} \mathrm{C}$, flowed by 8 to 10 minutes cleaning with alkaline detergent and disinfectant, and at last cold water rinse (Reinemann et al., 2003). Herd size more than 50 as a risk factor was significantly associated with Staphylococcus aureus, Salmonella Typhimurium, SPC and SCC in bulk tank (OR: 3, $\chi 2: 39$ and P < 0.0003, OR: 4.21, $\chi 2: 49$ and P< 0.00001, OR: 3.2, $\chi 2: 37$ and $\mathrm{P}<0.0003$, OR: 2.2, $\chi 2: 18.4$ and $\mathrm{P}<0.013$, respectively) as shown in table 5.

These findings agreed with Green et al. (2008). Higher bulk tank SCC was found in larger herds than in the smaller ones (Skrzypek, 2002; Skrzypek et al., 2003; Danko'w et al., 2004; Schewe et al., 2015). The present results disagreed with Norman et al. (2000), Oleggini et al. (2001) and Van Schaik et al. (2002). It would seem that the significant relationship between herd size, and SCC can be described by the fact that the increase in herd size played an important role in elaboration, and magnified the risk of infectious diseases, including mastitis. Another cause may be the fact that in small herds fewer cows were handled by one person, as a result of which animals were treated more individually than in larger herds (Skrzypek et al., 2004). Herd size more than 50 as a risk factor was significantly associated with total bacterial count in bulk tank milk. These results agreed with Goldberg et al. 1992, Gran et al. (2002); Jayarao et al (2004). Herd size (50 cows or more) as a risk factor was significantly associated with Salmonella in bulk tank milk based on the present results which agreed with Ruzante et al. (2010). Large herds may have a greater possibility of buying calves from more than one sources outside with the accompanying the risk of introducing Salmonella via subclinical shedders that was stressed by transportation. High cattle density can also additionally be a characteristic of large herds, and may promote Salmonella transmission (cummings et al., 2010). Herd size was frequently related to incidence of Salmonella in cattle dairy farms (Vaessen et al., 1998; Kabagambe et al., 2000; Warnick et al., 2001; Huston et al., 2002; Blau et al., 2005). Herd size had a great impact on bacterial counts in bulk tank milk (Goldberg et al., 1992; Gran et al., 2002; Jayarao et al., 2004; Elmoslemany et al., 2010). Storage manure indoor as a risk factor was significantly associated with Staphylococcus aureus, Salmonella Typhimurium, SPC and SCC in bulk tank (OR :3.27, $\chi 2$ : 59 and P < 0.00123, OR: 4.17, $\chi 2$ : 62.7 and $\mathrm{P}<0.00002$, OR: 6.21, $\chi 2: 89.7$ and $\mathrm{P}<0.000013$, OR: $2.17, \chi 2: 29.1$ and $\mathrm{P}<0.0021$, respectively) as shown in table 5. Cattle manure was recognized to contain and carry extensive range of microorganisms which can be pathogenic or non-pathogenic to both animals and humans (Godwin, 1997).

It is really worth citing that vectors, e.g., flies and vermin, which might also additionally spread and cause subsequent infections to other animals with pathogens from stored manure and flies, carry a number of mastitis-causing organisms that can colonize teat lesions, and consequently affect the SCC and SPC in bulk tank milk (Holt et al., 2007; Thomson et al., 2017). This requires frequent waste removal, once to several times per day depending on the housing, climate conditions (hot climate leads to drinking, and more frequent urination) and animal density. Animal manure should then be transported to a designated storage or disposal area, out of contact with animal (Manyi-Loh et al., 2016). Muddy bedding materials as a risk factor was significantly related to Staphylococcus aureus, Salmonella Typhimurium, SPC and SCC in bulk tank (OR :2.25, $\chi 2: 16$ and P<0.013, OR: 3.15, $\chi 2: 36$ and $\mathrm{P}<0.00015, \mathrm{OR}: 5, \chi 2: 66$ and $\mathrm{P}<$ 0.000023 , OR: $6.5, \chi 2: 86$ and $\mathrm{P}<0.0000003$, respectively) as shown in table 5 .

A wide variety of bedding materials are used in cattle barns as straw saw dust, wood and shavings. Bacterial concentrations in fresh and clean bedding were usually much lower than in concentrations in used bedding (Slaghuis et al., 1997). Schreiner and Ruegg (2003) reported that the main and common sources of exposure of environmental mastitis pathogens to the cow were the presence of moisture, mud and manure in the environment of the cow. One of the most vital and important steps affecting bulk tank microbial count and SCC was the transmission of dirt from dirt muddy bedding and soil to milk. Dirt basically was transmitted to milk when it was attached to the exterior of the teats and rinsed off all through milking operation (Murphy and Boor, 2000). The contamination of the teat with muddy soil was regarded one of the foremost important reasons for of elevated concentrations of microbial count in bulk tank milk, and consequently the level of Salmonella in bulk tank milk. Practices that expose the teat end to organic bedding sources, moist and muddy pens extended the risk of mastitis prevalence and milk contamination (Ruegg, 2006). Cleanliness of the cows (udder, teats and hocks) as a risk factor was significantly associated with Staphylococcus aureus, Salmonella Typhimurium, SPC and SCC in bulk tank (OR: 2.65, $\chi 2.19$ and $\mathrm{P}<0.023$, OR: 4.25, $\chi 2: 49$ and $\mathrm{P}<0.00023, \mathrm{OR}$. 5.15, $\chi$ : 69.7 and $\mathrm{P}<0.000001$ and $\mathrm{OR}: 4.21, \chi 2: 45.9$ and $\mathrm{P}<0.0012$, respectively) as shown in table 5 .

Cleanliness of the cows had a great and vital role in microbial contamination of the bulk tank milk, and had a great impact on the level of Staphylococcus aureus SPC and SCC level in bulk tank milk. These results agreed with Ruegg (2003), Schreiner and Ruegg (2003), Elmoslemany et al. (2009b), Piccinini et al. (2009), Zucali et al. (2011) and Cicconi-Hogan et al. (2013). Milking cows should be kept clean, groomed daily and therefore the udders and teats thoroughly should be washed before every milking because the coat and skin were always dirty as this might act as a source of spoilage bacteria. . Cleaning and removal of soil particles, bedding material and manure from the udder and flanks was very essential to prevent the entry of many types of bacteria into the bulk tank milk (Zelalem et al., 2011). 
Summer season as a risk factor was significantly associated with Staphylococcus aureus, Salmonella Typhimurium, SPC and SCC in bulk tank (OR: 3.21, $\chi 2$ : 39 and $\mathrm{P}<0.00012$, OR: 2.15, $\chi 2$ : 19.7 and P $<0.02, \mathrm{OR}$ : 4.24, $\chi 2: 42.7$ and $\mathrm{P}<0.00014$ and OR. 3.27, $\chi 2.47 .8$ and $\mathrm{P}<0.0002$, respectively) as shown in table 6.

The results agreed with Leslie (1996), Sargeant et al. (1998), Norman et al. (2000), Ruegg and Tabone (2000), Zadnik et al. (2001), Berry et al. (2006), Lievaart et al. (2007), Olde Riekerink et al. (2007), Summer et al. (2007), Elmoslemany et al. (2010) and Zucali et al. (2011), Cicconi-Hogan et al. (2013). They reported that bulk tank milk SCC counts were higher in summer, and was perhaps related to the influence and impact of higher temperature and humidity on mastitis risk. Green et al. (2006) suggested that the rise in BMSCC during this period was that the consequences of arise in chronic high individual cow SCC (ICSCC), and disagreed with Berry et al. (2006) who reported that BMSCC was commonly lowest during April, and highest in November. It was additionally recognized that favorable temperature and humidity in the summer played a critical role in favoring growth and quantity of environmental bacteria in bedding material (Harmon 1994). Heat stress may additionally amplify the cow's susceptibility to infection via both lowering host resistance or by increasing host exposure to pathogens (Morse et al., 1988). Variations and fluctuation in temperature and humidity can have a strong impact on bacterial counts in milk. Summer season had a great impact on bulk tank total aerobic count as shown by Izsler (2010). Prevalence of Staphylococcus aureus in bulk tank was higher in summer. These results disagreed with findings of Makovec and Ruegg (2003) and Olde Riekerink et al. (2007) who observed a high incidence of Staphylococcus aureus in bulk tank milk during December and January. Salmonella incidence in bulk tank milk used to be higher in summer season. The present results which agreed with Holley et al. (2006) and Semenov et al. (2007). They mentioned that survival of Salmonella in the environment ought to additionally increase in the summer months, although soil composition, moisture and temperature fluctuation appeared to play a role. Region variation as a risk factor was significantly associated with Staphylococcus aureus, Salmonella Typhimurium,

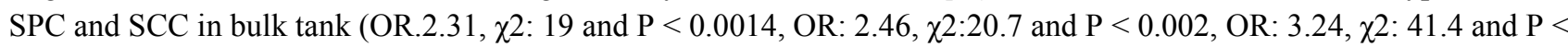
0.0012 and OR: 2.17, $\chi 2: 27.8$ and $\mathrm{P}<0.0031$, respectively) as shown in table 6 .

Delta region was significantly associated with Staphylococcus aureus, Salmonella Typhimurium, SPC and SCC in bulk tank. These regional variations ought to be variant in climate and agricultural tradition. The climate and geographical aspects and features of region had a great impact on the degree of bacterial contamination and SCC level in bulk tank milk. The results agreed with Raghib et al. (2004). A possible reason for the elevation of TBC in Delta region ought to be due to poor hygienic condition of the collection tanks distributed by milk collectors. This finding agreed with Reinemann et al. (2000). PCR identification of virulence gene ( $h l g$ ) of Staphylococcus aureus isolates revealed a product of approximate size $937 \mathrm{bp}$. The gene ( $\mathrm{llg}$ ) which was found in 13 (54\%) Staphylococcus aureus isolates (figure 3); these results disagreed with El-baz et al. (2016) (81.1\%), Maeda et al. (2016) and Ali (2017) (90\%). Hemolysins were produced by Staphylococcus aureus isolates, and played a vital role in the pathogenesis of the disease caused by Staphylococcus aureus (Lo et al., 2011). $\gamma$-hemolysin ( $h l g$ ) gene was found within a $4.5 \mathrm{~kb}$ ScaI fragment of Staphylococcus aureus chromosome. It was another form of pore forming toxin, unlike $\alpha$-hemolysin. The $h l g$ gene consisted of two transcription units (the first one encodes $\gamma$-hemolysin-A ( $H \lg A$ ) like protein, a class $\mathrm{S}$ (slow) component, and the second one codes $\gamma$-hemolysin $\mathrm{C}(h \lg C)$ and $\gamma$-hemolysin B ( $h l g B)$, a category of $\mathrm{F}$ (fast) and $\mathrm{S}$ (slow) component (Divyakolu et al.2019). Staphylococcal $\gamma$-hemolysin ( $h l g$ ) consisted of polypeptides nominated as $\mathrm{S}$ (Slow), ( $h l g A$ or $h \lg C$ ) and $\mathrm{F}$ (Fast), $(h \lg B)$, which coordinated in lysis of target cells, where the $\mathrm{S}$ components were proposed to affect cell type susceptibilities to those toxins Meyer et al. (2019). These proteins after determining of their cell targets undertook conformational changes and formed oligomeric complexes. This process resulted in transmembrane-pore formation, and also the cell death (Meyer et al. 2019). This toxin targeted polymorph nuclear cells, monocytes, macrophages and erythrocytes (Vandenesch et al. 2012). $\gamma$-hemolysin, belonging to a group of genes that coded for both $h \lg A$ and $h \lg C$ as the $\mathrm{S}$ (slow) component, or $h \lg B$ as the $\mathrm{F}$ (fast) component which was found within the core genome (Du Mont et al. 2014). On the other hand, molecular identification of sopB (SigD) virulence gene for Salmonella Typhimuriym isolates revealed that the PCR amplification with $(\operatorname{sop} B)$ gene specific primers was conducted with genomic DNA, which revealed in a product of approximate size $517 \mathrm{bp}$. sopB gene, was found in all Salmonella Typhimurium isolates (100\%) figures 1 and 2. The Salmonella outer protein (sopB) gene well was conserved in all Salmonella Typhimurium strains. These results agreed with Mirold et al. (2001) who stated that the sopB gene was found in the SPI-5 pathogenicity island, and was detected in all sequenced Salmonella Typhimurium strains. The outer proteins (Sops) of Salmonella were playing a definite role in the manipulation of various stages of polymorphonuclear leukocyte influx, and rearrangement of the cytoskeleton (Boyle et al., 2006). SopB/SigD, an inositol phosphatase, was needed for fluid and chloride secretion, neutrophil recruitment, and played an important role in causing deformation to epithelial barrier function during the invasion (Bertelsen et al., 2004). It mediated the virulence by inhibiting inositol phosphate signaling pathways (Marcus et al. 2001; Marcus et al., 2002). SopB/SigD also had a great antiapoptotic activity, and so on they played an important and distinct role in the intracellular replication because of the up keeping and maintain of Akt activation (García-Gil et al., 2018). 


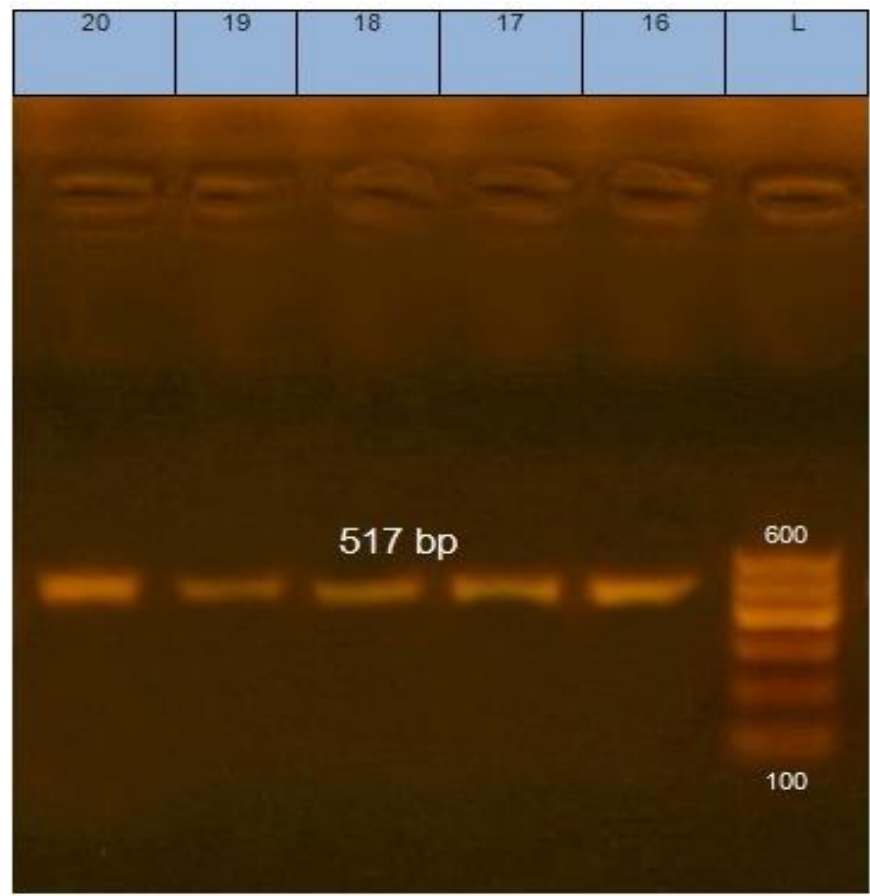

Figure 1. Agarose gel shows a PCR amplified product of 517 bp. of (sopB) virulence gene for Salmonella Typhimurium, lanes (16) to (20): samples positive for sopB gene, Lane (L): MW 100bp ladder (DNA marker).

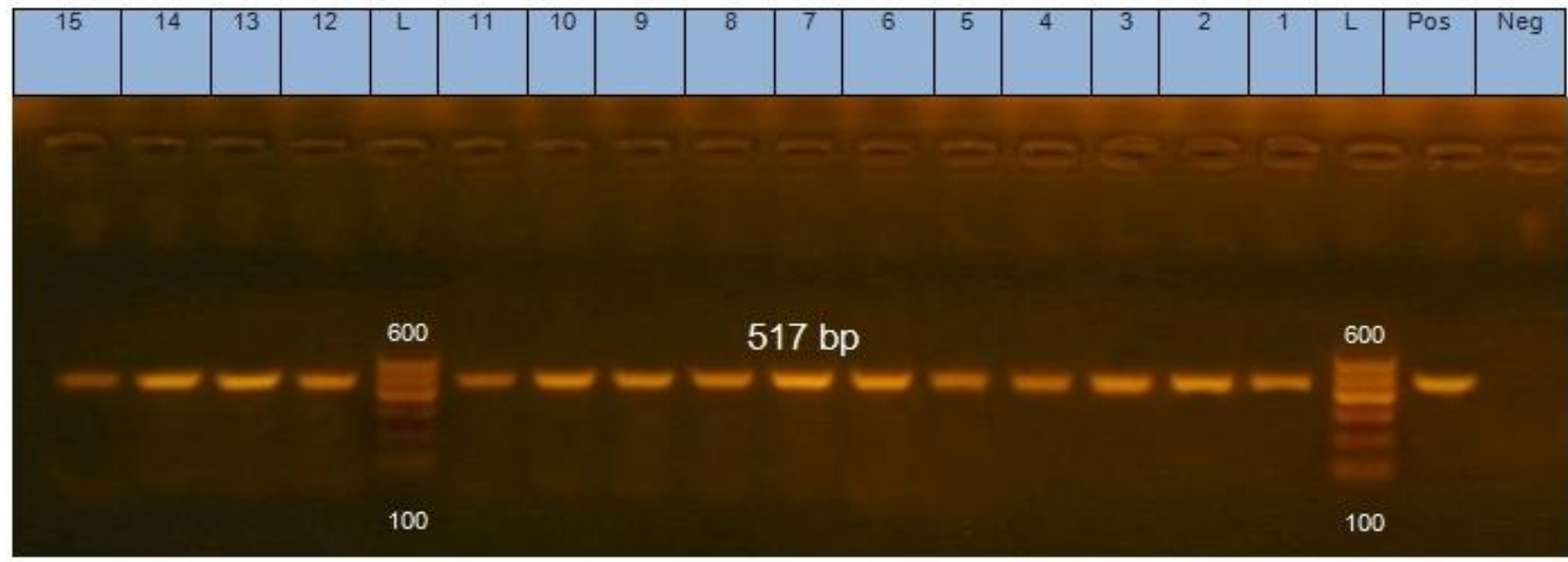

Figure 2. Agarose gel shows a polymerase chain reaction (PCR) amplified product of 517 bp of ( $\operatorname{sopB}$ ) virulence gene for Salmonella Typhimurium, lanes (1) to (15): samples positive for sopB gene, Lane (positive): positive control, Lane (Negative): Negative control, Lane (L): MW 100bp ladder (DNA marker).

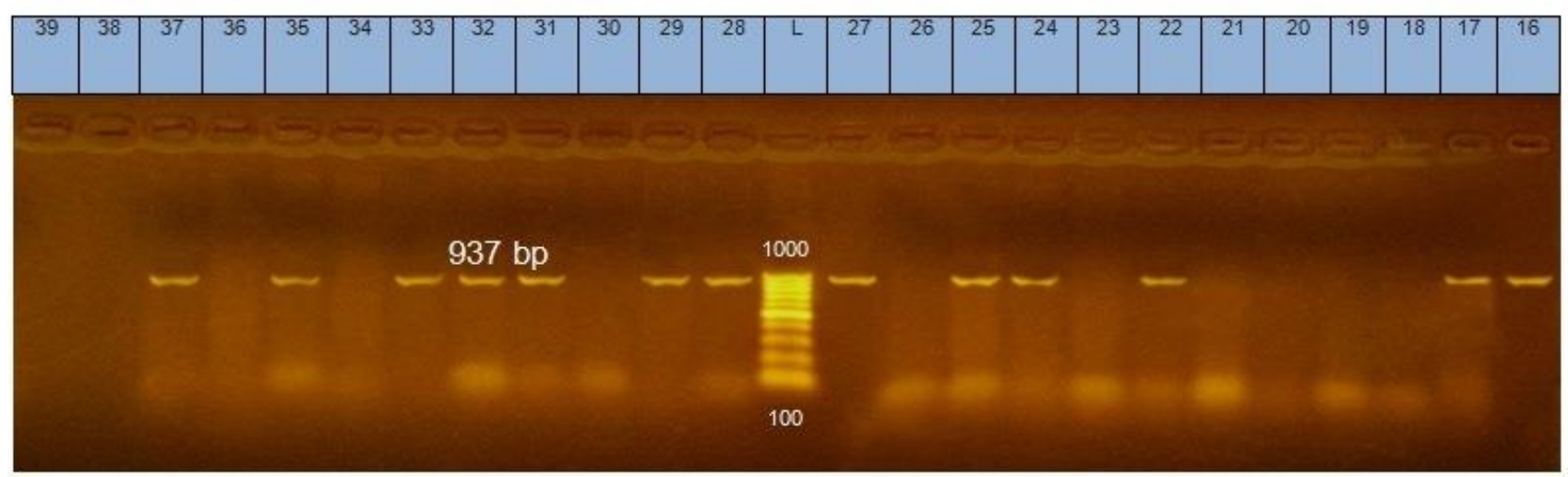

Figure 3. Agarose gel shows a PCR amplified product of 937 bp. of gamma hemolysin (hlg) gene for Staphylococcus aureus, lanes $(16,17,22,24,25,27,28,29,31,32,33,35,37)$ : samples positive for hlg gene, Lane (L): MW 100bp. ladder (DNA marker). 
Phylogenetic and partial gene sequence analysis of hlg gene of Staphylococcus aureus that was generated using neighbor joining in MEGA6 showed a clear clustering of isolated Egyptian Staphylococcus aureus strain, and different Staphylococcus aureus strains uploaded from gene bank as shown in figures 6 and 7. Sequence distance of Staphylococcus aureus hlg virulence gene was created by the MegAlign module of Laser gene DNA Star. Sequence identities between the isolated Egyptian strain and different Staphylococcus aureus strains were uploaded from gene bank revealing a $95.8 \%$ to $98.9 \%$ homology as shown in figure 7 . Analyzing of nucleotide sequence of $h l g$ virulence gene of the Egyptian isolated strain in the current study showed a 98.9\% nucleotide identity with the American Staphylococcus aureus strain FDAARGOS-412 (accession no. CP023500) by Minogue et al. (2017), the Belgium Staphylococcus aureus strain NMR08 (accession no. CP023560) by Coppens et al. (2017), the Korean Staphylococcus aureus strain CN1 (accession no. CP003979) by Chen et al. (2013), the Japanese Staphylococcus aureus strains TMUS2126 and TMUS2134 (accession no. AP014652 and AP014563, respectively) by Yamaguchi et al. (2015) and a 98.1\% nucleotide identity with the Taiwan Staphylococcus aureus strain M013 (accession no. CP003166) by Huang et al. (2012), the Taiwan (MRSA) methicillin resistant Staphylococcus aureus strains SA967 and SA40 (accession no. CP003603 and CP003604) by Chen et al. (2013). Amino acids alignment report of the sequenced 934 amino acids of (hlg) Staphylococcus aureus virulence gene of Egyptian isolated strain (using CLUSTALW) multiple sequence alignment program version 1.83 of MegaAlign module of laser gene DNA star as shown in figure 8 showed a great homology between the Staphylococcus aureus Egyptian strain, and the different Staphylococcus aureus strains uploaded from gene bank. Phylogenetic and partial gene sequence analysis of sopB gene of Salmonella that was generated using a neighbor joining in MEGA6 as shown in figures 4 and 5 showed a clear clustering of isolated Egyptian Staphylococcus aureus strain and different $S$. aureus strains uploaded from gene bank. Nucleotide sequence distance of Salmonella Typhimurium sopB virulence gene was created by the MegaAlign module of Laser gene DNA Star. Nucleotide Sequence identities between the isolated Egyptian strain and different Salmonella strains uploaded from gene bank revealed a $98.6 \%$ to $100 \%$ homology as shown in figure 4 . Nucleotide sequence analysis of sopB virulence gene of the Egyptian isolated strain showed a 100\% nucleotide identity with, the Taiwan Salmonella Typhimurium strain BL10 (accession no. CP024619) by Hong et al. (2018), the English Salmonella Typhimurium strain VNP151-sc-2315230 (accession no. LT795114) by pathogen informatics (2017), the American Salmonella Typhimurium RM1160 strain (accession no. CP022658) by Parker et al. (2017), the English Salmonella Typhimurium strain DT2 (accession no. HG326213) by Kingsley et al. (2013), the English Salmonella Typhimurium strain DT104 (accession no. HF937208) by Mather et al. (2013), Salmonella Typhimurium var.5 strain CFSAN001921 (accession no. CP006048) by Hoffman et al. (2013), the English Salmonella Typhimurium strain U288 (accession no. CP003836) by Hotton et al. (2012), the American Salmonella Typhimurium strain 798 (accession no. CP003386) by Petersson et al. (2012), the American Salmonella Typhimurium strain Uk1 (accession no. CP002614) by (Luo et al. (2011), the American Salmonella Typhimurium strain ST4/74 (accession no. CP002487) by Richardson et al. (2011), the Japanese Salmonella Typhimurium strain T000240 (accession no. AP011957) by Izumiyia et al. (2011), the Salmonella Typhimurium strain SL1344 (accession no. FQ312003) by Kroger et al. (2012), the American Salmonella Typhimurium strain 14028S (accession no. CP001363) by Jarvik et al. (2010). Amino acids alignment reported of the sequenced 514 amino acids of Salmonella Typhimurium $(s o p B)$ virulence gene of Egyptian isolated strain (using CLUSTALW) multiple sequence alignment program version 1.83 of MegaAlign module of laser gene DNA star as shown in figure 9 showed a great homology between the Egyptian strain Salmonella Typhimurium and the different Salmonella Typhimurium strains uploaded from gene bank.

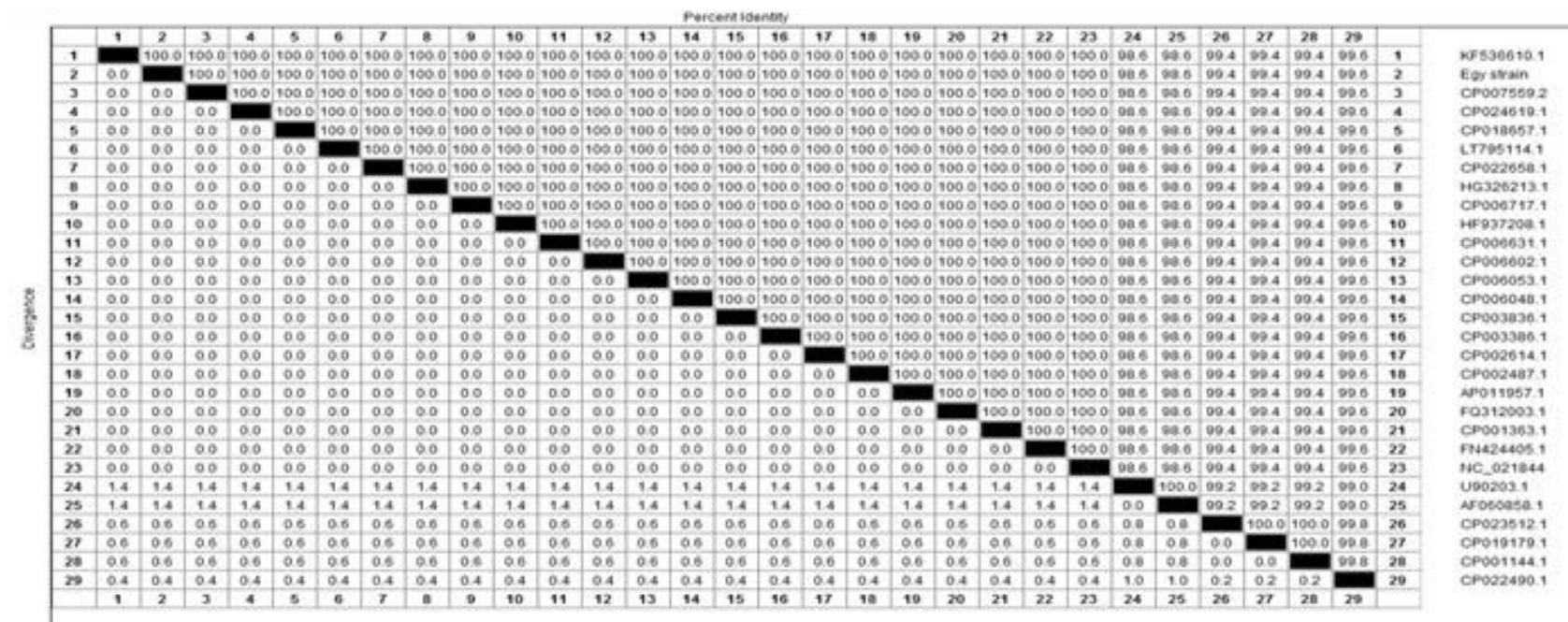

Figure 4. Nucleotide Sequence distance analysis of Salmonella Typhimurium (sopB) virulence gene between the Egyptian isolated strain and different Salmonella Typhimurium strains uploaded from gene bank. 


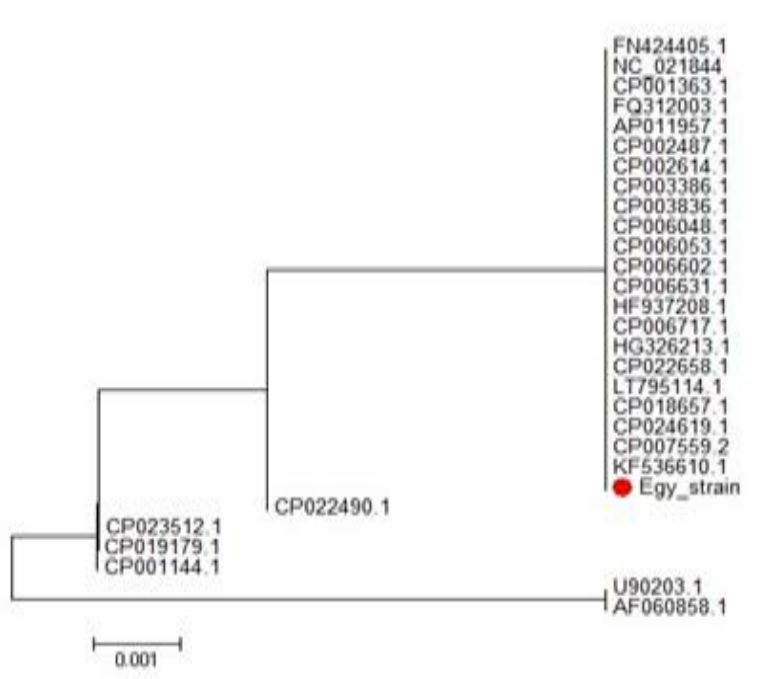

Figure 5. Phylogenetic tree for Salmonella Typhimurium (sopB) virulence gene partial nucleotide sequences that was generated using a neighbor joining in MEGA6. It shows a clear clustering of the Egyptian isolated strain and different Salmonella Typhimurium strains uploaded from gene bank.

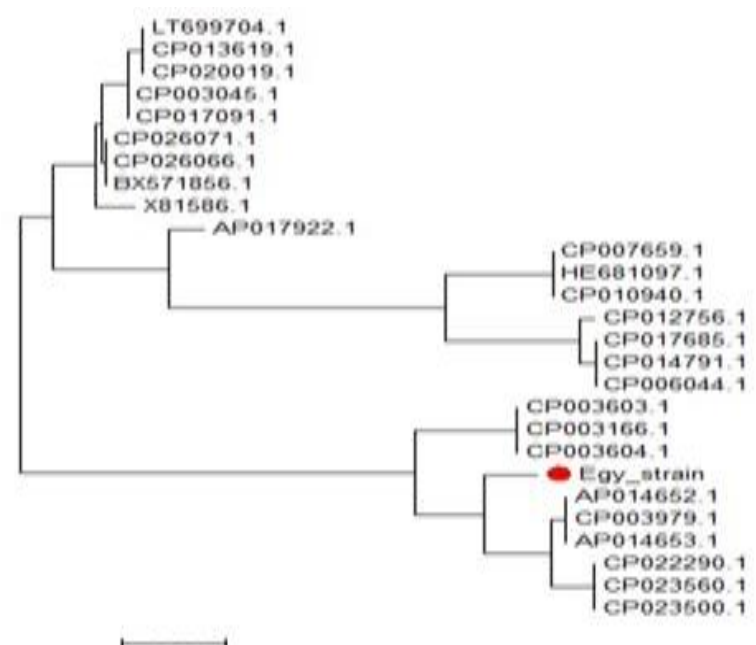

Figure 6. Phylogenetic tree for Staphylococcus aureus ( $h l g$ ) virulence gene partial nucleotide sequences that was generated using a neighbor joining in MEGA6. It shows a clear clustering of the Egyptian isolated strain and different $S$. aureus strains uploaded from gene bank.

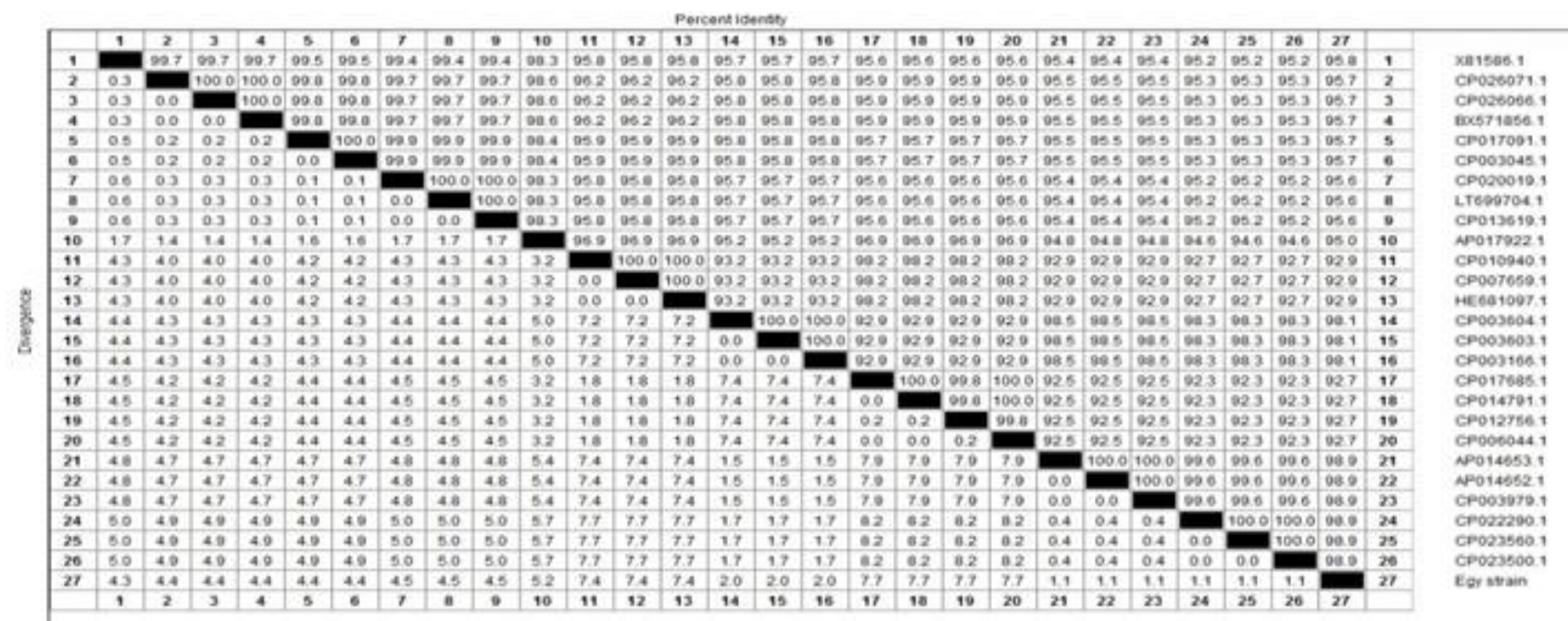

Figure 7. Nucleotide sequence distance analysis of (hlg) Staphylococcus aureus virulence gene between the Egyptian isolated strain and different Staphylococcus aureus strains uploaded from gene bank

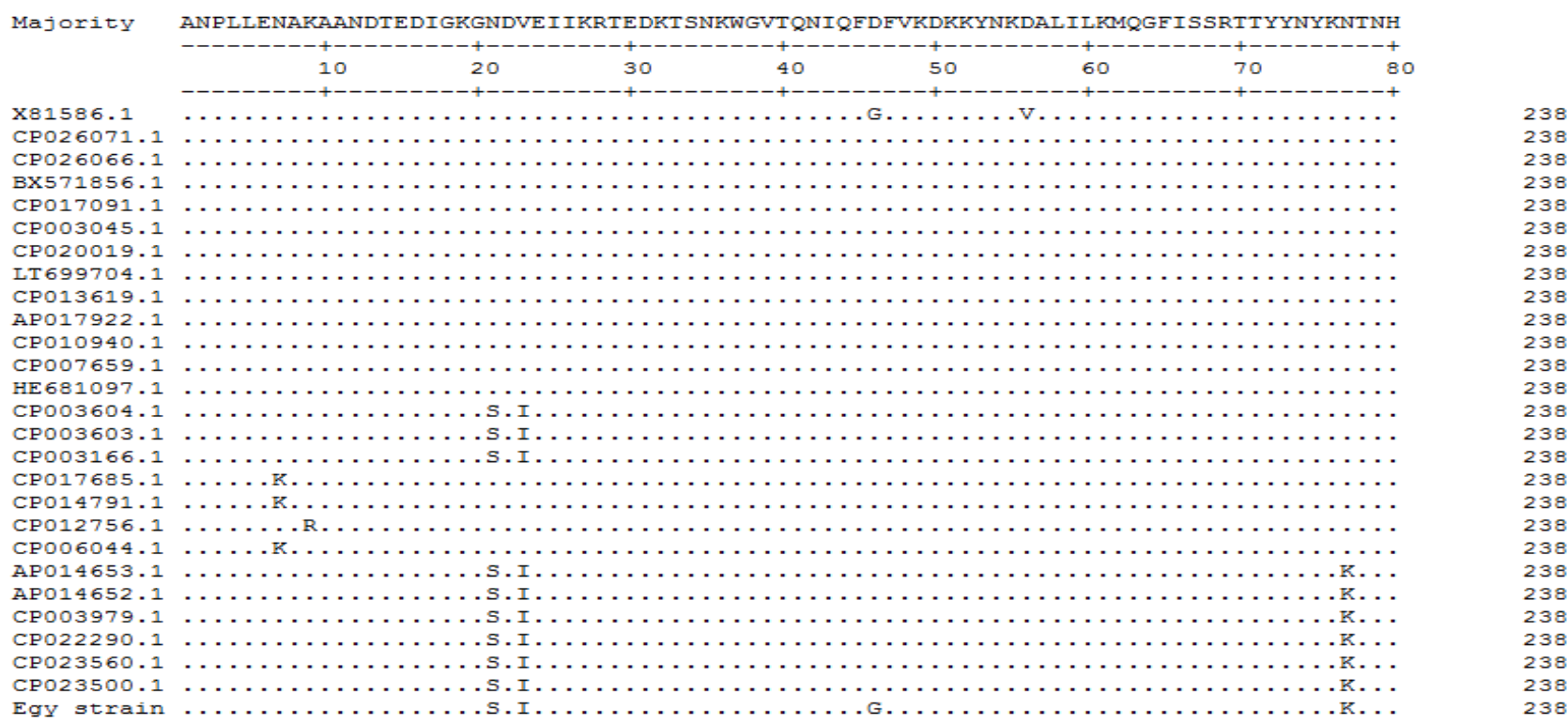


Majority TYGRMMDVTHAIKRSTHYGNSYLDGHRVHNAFKNRNYTVKYEVNWKTHEIKVKGQN-YEHE-ISQIIRCYVY

\begin{tabular}{|c|c|c|c|c|c|c|}
\hline 250 & 260 & 270 & 280 & 290 & 300 & 310 \\
\hline
\end{tabular}

$\mathrm{X} 81586.1$

CP026071.1

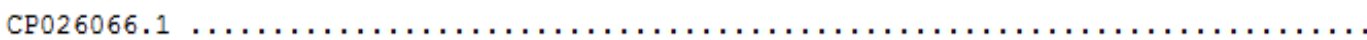

BX571856.1

CP017091.1

CP003045.1

CP020019.1

LT699704.1

CP013619.1

AP017922.1

CP010940.1

CP007659.1

HE 681097.1

CP003604.1

CP003603.1

CP003166. 1

CP017685.1

CP014791.1

CP012756.1

CP006044.1

AP014653.1

AP014652.1

CP003979.1

CP022290.1

$\mathrm{CP} 023560.1$

CP023500.1

Egy strain

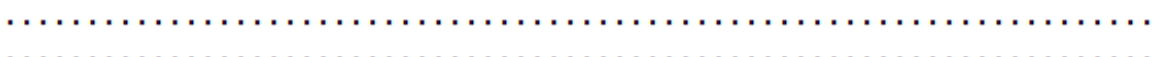

Figure 8. Deduced amino acids alignment of (hlg) Staphylococcus aureus virulence gene of Egyptian isolated strain using (CLUSTALW) multiple sequence alignment program version 1.83 of MegaAlign module of laser gene DNA star and different Staphylococcus aureus strains uploaded from gene bank

Majority

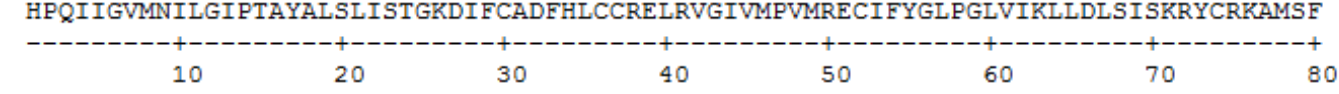

KF536610.1

Egy strain

CP007559.2

CP024619.1

CP018657.1

LT795114.1

CP022658.1

HG326213.1

CP006717.1

HF937208.1

CP006631.1

CP006602.1

CP006053.1

CP006048.1

СР003836.1

CP003386.1

CP002614.1

CP002487.1

AP011957.1

FQ312003.1

CP001363.1

FN424405.1

NC_021844

U9 0203.1

AF0 60858.1

CP023512.1

CP019179.1

CP001144.1

CP022490.1

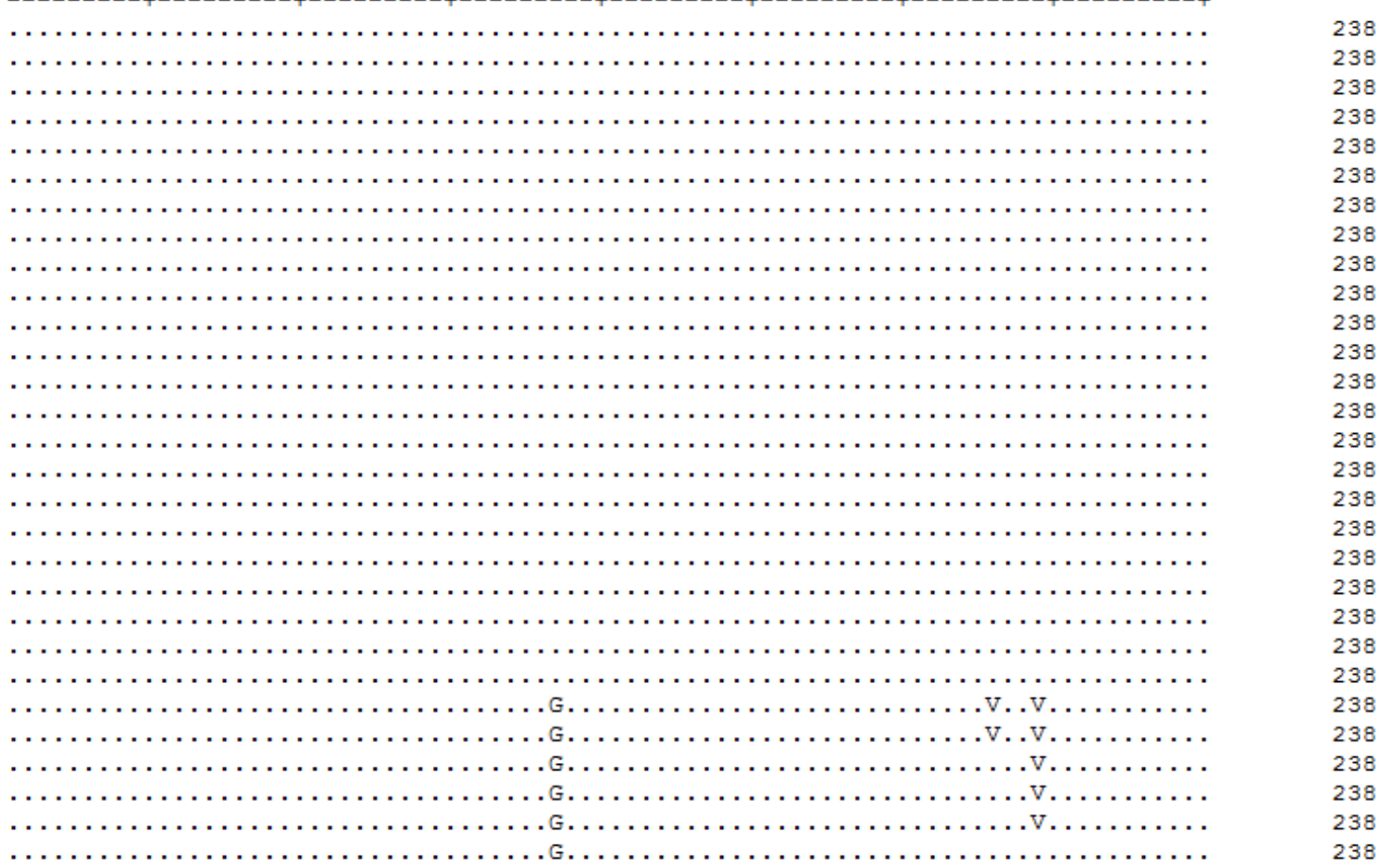




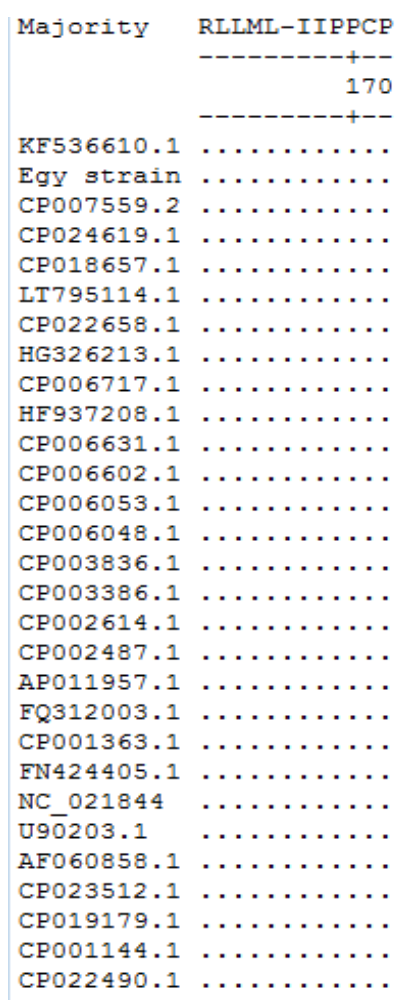

Figure 9. Deduced Amino acids alignment of Salmonella Typhimurium (sopB) virulence gene of Egyptian isolated strain using (CLUSTALW) multiple sequence alignment program version 1.83 of MegaAlign module of laser gene DNA star and different Salmonella Typhimurium strains uploaded from gene bank

\section{CONCLUSION}

The results of present study provided an allocation for the elaborateness of more efficacious preventive programs for controlling the mastitis and bacteriological quality of bulk tank milk, enhancement of raw milk quality, decreasing and monitoring the economic losses caused by the disease to dairy industry. Analyzing of nucleotide sequence of $h l g$ virulence gene of the Staphylococcus aureus Egyptian isolated strain in the current study showed a 95.8\% to $98.9 \%$ nucleotide identity with different Staphylococcus aureus strains uploaded from gene bank. Nucleotide sequence identities between the isolated Egyptian Salmonella strain and different Salmonella strains uploaded from gene bank revealed a $98.6 \%$ to $100 \%$ homology.

\section{DECLERATIONS}

\section{Author`s contributions}

M.F and H.M designed the concept of the review article, and M.F and H.M designed and performed study design and the economic frame work .All authors shared in writing, reviewed and approved the manuscript. All authors read and approved the final version.

\section{Competing interests}

The authors declared that they have no competing interests.

\section{Acknowledgments}

This work was supported by Department of Udder Health and Neonates, Animal Reproduction Institute, ARC. ElHaram, Giza, for their support.

\section{REFERENCES}

Abdallah MI (2002). Hygienic quality of concentrated and raw milks sold in Damietta governorate. Ph.D thesis, Food control department, faculty of veterinary medicine, Zagazig University, Available at: http://hdl.handle.net/123456789/18

Abo-shama UH (2013). Detection of nontyphoidal Salmonella isolated from food products and clinical cases by conventional bacteriological methods in Sohag Governorates. Suez Canal veterinary. Medicine. Journal, 18 (2): 69-85. Available at: http://vet.scuegypt.edu.eg/attach/m6.pdf.

Addis Z, Kebede N, Sisay Z, Alemayehu H, Yirsaw A and Kassa T (2011). Prevalence and antimicrobial resistance of Salmonella isolated from lactating cows and in contact humans in dairy farms of Addis Ababa: a cross sectional study. BMC Infectious Diseases, 11: 222-228. DOI: https://doi.org/10.1186/1471-2334-11-222.

Amal M. Eid (2014). Molecular identification of some contagious microorganisms causing food poisoning from bulk tank milk in Gharbia Governorate. Benha Veterinary Medical Journal, 27 (2): 29-47. Available at: http://bvmj.bu.edu.eg/issues/27-2/4.pdf 
American public health Association (APHA) (1992). Standard methods for examination of dairy products. INC., 16 ${ }^{\text {th }}$ ed. New york. Available at: https://www.scirp.org/(S(i43dyn45teexjx455qlt3d2q

American Public Health Association (APHA) (2004). Standard methods for the examination of dairy products. INC., 17 ${ }^{\text {th }}$ ed. American Public Health Association. Washington D.C. Available at: https://www.apha.org

Anderson KL, Lyman R, Moury K, Ray D, Watson DW and Correa MT (2012). Molecular epidemiology of Staphylococcus aureus mastitis in dairy heifers. Journal of Dairy Science, 95: 4921-4930. DOI: https://doi.org/10.3168/jds.2011-4913.

Arnold M and Bewley J (2011). Staphylococcus aureus Mastitis. University of Kentucky College of Agriculture, Food and Environment, Lexington, KY. Available at: http://www2.ca. uky.edu/agc/pubs/id/id190/id190.pdf.

Axelsson A (2004). A comparison between bulk tank milk samples and individual milk samples from dairy herds in Uruguay. Degree project. Faculty of veterinary medicine. The Swedish University of Agricultural Sciences (SLU), Uppsala, Sweden. Available at: https://stud.epsilon.slu.se/11172/1/axelsson_a_170926

Bach A, Valls N, Solans A and Torrent T (2008). Associations between non dietary factors and dairy herd performance. Journal of Dairy Science, 91: 3259-3267. DOI: https://doi.org/ 10.3168/jds.2008-1030.

BAM on line (2009). Bacteriological Analytical Manual on line. US. Food and drug administration center for food safety and applied nutrition. Available at: https://www.fda.gov/food/laboratory-methods-food/bacteriological-analytical-manual-bam

Barkema HW, Schukken YH, Lam TJGM, Beiboer ML, Benedictus G and Brand A (1998). Management practices associated with low, medium, and high somatic cell counts in bulk milk. Journal of Dairy Science, 81: 1917-1927. DOI: https://doi.org/.10.3168/jds.S0022-0302(98)75764-9

Barkema HW, Schukken YH, Lam TJGM, Beiboer ML, Benedictus G and Brand A (1999). Management practices associated with the incidence rate of clinical mastitis. Journal of Dairy Science, 82: 1643-1654. DOI: https://doi.org/10.3168/jds.S0022-0302(99)75393-2

Barnouin J, Chassagne M, Bazin S and Boichard D (2004). Management practices from questionnaire surveys in herds with very low somatic cell score through a national mastitis program in France. Journal of Dairy Science, 87: 3989-3999. DOI: https://doi.org/10.3168/jds.S0022-0302(04)73539-0

Bava L, Zucali M, Brasca M, Zanini L and Sandrucci A (2009). Efficiency of cleaning procedure of milking equipment and bacterial quality of milk. Italian Journal of Animal. Science, 8 (2): 387-389. Available at: https://www.tandfonline.com/loi/tjas20.

Beli E (2015). Microbiological quality of raw milk at farm, collection and manufactory level in Albania. Albanian Journal of Agricultural Sciences, 14: 344-349.Available at: http://ajas.ubt.edu.al/wp-content/uploads/2018/05/25 ELVIRA-BELI-pp-344-349

Benić M, Habrun B and Kompes G (2012). Clinical and epidemiological aspects of cow mastitis caused by Staphylococcus aureus and its methicillin-resistant strains. Rad 511- Medical Sciences, 37: 113- 122. Available at: https://pdfs.semanticscholar.org/77c4/6780c04d3605fa59665c73d012171a9d7876

Berry DP, O'Brien B, O'Callaghan EJ, Sullivan KO and Meaney WJ (2006). Temporal trends in bulk tank somatic cell count and total bacterial count in Irish dairy herds during the past decade. Journal of Dairy Science, 89: 4083-4093. DOI: https://doi.org/10.3168/jds.S0022-0302(06)72453-5

Bertelsen LS, Paesold G, Marcus SL, Finlay BB, Eckmann L and Barrett KE (2004). Modulation of chloride secretory responses and barrier function of intestinal epithelial cells by the Salmonella effector protein SigD. American Journal of cell Physiology, 287: (4): 939-948. DOI: https://doi.org/ 10.1152/ajpcell.00413.2003

Blau DM, McCluskey BJ, Ladely SR, Dargatz DA, Fedorka-Cray PJ and Ferris KE (2005). Salmonella in dairy operations in the United States: prevalence and antimicrobial drug susceptibility. Journal of Food. Protection. 68 (4): 696-702. DOI: https://doi.org/10.4315/0362-028x-68.4.696

Blowey and Edmondson (2010). Mastitis Control in Dairy Herds, $2^{\text {nd }}$ Edition. Avilable at: lactoscan.com/editor/ufo/manuals/SCC/Mastitis_Control_in_Dairy_Herds_2 ${ }^{\text {nd }}$ (veterinarystudent.blogfa.com).pdf

Bonfoh B, Wasem A, Traore A, Fane A, Spillmann H, Simbe C, Alfaroukh I, Nicolet J, Farah Z and Zinsstag J (2003). Microbiological quality of cow's milk taken at different intervals from the udder to the selling point in Bamako (Mali). Food Control, 14: 495- 500. Available at: https://www.infona.pl/resource/bwmeta1.element.elsevier-c99bfeeb-6899-3c24-aaae-c4aa482ae451

Boyle EC, Brown NF and Finlay BB (2006). Salmonella enterica serovar Typhimurium effectors SopB, SopE, SopE2, and SipA disrupt tight junction structure and function. Cell Microbiology, 8: 1946-1957. DOI: https://doi.org/10.1111/j.1462-5822.2006.00762.x

Capurro A, Aspan A, Ericsson Unnerstad H, Persson Waller K and Artursson K (2010). Identification of potential sources of Staphylococcus aureus in herds with mastitis problems. Journal of Dairy Science, 93: 180-191. DOI: https://doi.org/10.3168/jds.2009-2471

Chambers JV (2002). The microbology of raw milk. In: Dairy microbology handbook $3^{\text {rd }}$ edition. R.K. Robinson, ed. John Wiley \& Sons, Inc., New York. Available at: http://www.sciepub.com/reference/70238

Chassagne M, Barnouin J and Le Guenic M (2005). Expert assessment study of milking and hygiene practices characterising very low somatic cell score herds in France. Journal of Dairy Science, 88: 1909-1916. Available at: https://doi.org/10.3168/jds.S0022-0302(05)72867-8

Chen CJ, Unger C, Hoffmann W, Lindsay JA, Huang YC and Gotz F (2013). Characterization and comparison of 2 distinct epidemic community-associated methicillinresistant Staphylococcus aureus clones of ST59 lineage. PLoS ONE, 8 (9): E63210. DOI: https://doi.org/10.1371/journal.pone.0063210

Chen Y, Chatterjee SS, Porcella SF, Yu Ys and Otto M (2013). Complete genome sequence of a panton- valentine leukocidin- negative community- associated methicillinresistant Staphylococcus aureus strain of sequence type 72 from Korea. PLoS ONE, 8 (8): E72803. Available at: https://www.ncbi.nlm.nih.gov/nuccore/CP003979.

Christiansson A, Bertilsson J and Svensson B (1999). Bacillus cereus spores in raw milk: factors affecting the contamination of milk during the grazing period. Journal of Dairy Science, 82: 305-314. DOI: https://doi.org/10.3168/ids.S0022-0302(99)75237-9

Chye FY, Abdullah A and Ayob MK (2004). Bacteriological quality and safety of raw milk in Malaysia. Food Microbiology, 21: 535-541. DOI: https://doi.org/10.1016/j.fm.2003.11.007

Cicconi-Hogan KM, Gamroth M, Richert RM, Ruegg PL, Stiglbauer KE and Schukken YH (2012). Risk factors associated with bulk tank standard plate count, bulk tank coliform count, and the presence of Staphylococcus aureus on organic and conventional dairy farms in the United States. Journal of Dairy Science, 96: 7578-7590. DOI: https://doi.org/10.3168/jds.2012-6505

Cicconi-Hogan KM, Gamroth M, Richert RM, Ruegg PL, Stiglbauer KE and Schukken YH (2013). Associations of risk factors with somatic cell count in bulk tank milk on organic and conventional dairy farms in the United States. Journal of Dairy Science, 96: 3689-3702. DOI: https://doi.org/10.3168/jds.2012-6271

Collee J, Miles R and Watt B (1996). Tests for identification of bacteria in tests for identification of bacteria. In "Mackie and McCartney, Practical Medical Mic robiology." $14^{\text {th }}$ ed. New York: Churchill Livingstone, Available at: https://www.scirp.org/(S(lz5mqp453edsnp55rrgjct55))/ReferenceID=1838880

Cooney J, Kienle Z, Foster TJ and Otoole PW (1993). The gamma-hemolysin locus of Staphylococcus aureus comprises three linked genes, two of which are identical to the genes for the $\mathrm{F}$ and $\mathrm{S}$ components of leukocidin. Infection and immunity, pp. 768-771. Available at https://www.ncbi.nlm.nih.gov/pmc/articles/PMC302792/pdf/iai00014-0408.pdf

Coppens J, Britto Xavier B, Vanjari L, Vemu L, Lammens C, Goossens H and Malhotra-Kumar S (2017). Direct Submission, Medical Microbiology, University of Antwerpen, Universitietplein, Wilrijk, Antwerpen 2610, Belgium. Available at: https://www.ncbi.nlm.nih.gov/nuccore/CP023560

Cruickshank R, Duguid JP, Marmion BP and Swain RHA (1975). Medical microbiology. The practice of Medical Microbiology, $12^{\text {th }}$ ed. Vol. II Churchill Living stone, Edinburgh, London and New York, 2: 170-188. Available at: https://www.abebooks.com/book-search/title/medical-microbiology/author/robert-cruickshank/

Cummings KJ, Warnick LD, Elton M, Gröhn YT, McDonough PL and Siler JD (2010). The effect of clinical outbreaks of salmonellosis on the prevalence of fecal Salmonella shedding among dairy cattle in New York. Foodborne Pathogens and Disease, 7: 815-823. DOI: https://doi.org/ 10.1089/fpd.2009.0481

Da Costa LB, Rajala-Schultz PJ, Hoet A, Seo KS, Fogt K and Moon BS (2014). Genetic relatedness and virulence factors of bovine Staphylococcus aureus isolated from teat skin and milk. Journal of Dairy Scence, 97: 6907-6916. Available at: DOI: https://doi.org/10.3168/jds.2014-7972

Da Costa PJ, Rajala-Schultz GM and Schuenemann LB (2016). Management practices associated with presence of Staphylococcus aureus in bulk tank milk from Ohio dairy herds. Journal of. Dairy Science, 99: 1364-1373. DOI: https://doi.org/10.3168/jds.2015-9870

Danko'w R, Wo jtowski J and Fahr RD (2004). Hygienic quality of raw milk in relation to methods of production and storage. Medycyna Weterynaryjna, 60: 46-50. DOI: https://doi.org/10.1111/j.1439-0442.2004.00611.x

Down PM (2016). Optimising decision making in mastitis control. PhD thesis, University of Nottingham. Available at: http://eprints.nottingham.ac.uk/33913/1/PhDThesis_PeterDown_10.06.2016.pdf 
Du Mont AL, Yoong P, Liu X, Day CJ, Chumbler NM, James DB, Alonzo F, Bode NJ, Lacy DB, Jennings MP Torres VJ et al. (2014). Identification of a crucial residue required for Staphylococcus aureus Luk AB cytotoxicity and receptor recognition. Infection and Immunity, 82: 1268-1276. DOI: https://doi.org/ 10.1128/IAI.0144413. Epub 2013.

Duan J, Li M, Hao Z, Shen X, Liu L, Jin Y, Wang S, Guo Y, Yang L, and Wang L (2018). Subinhibitory concentrations of resveratrol reduce alpha-hemolysin production in Staphylococcus aureus isolates by downregulating saeRS. Emerging Microbes and Infections, 7: 136. DOI: https://doi.org// 10.1038/s41426-018-0142-x.

Dufour S, Barkema HW, DesCôteaux L, DeVries TJ, Dohoo IR, Reyher K, Roy JP and Scholl DT (2010). Development and validation of a bilingual questionnaire for measuring udder health related management practices on dairy farms. Preventive Veterinary Medicine, 95: 74-85. DOI: https://doi.org/ 10.1016/j.prevetmed.2010.02.018.

Dufour S, Dohoo IR, Barkema HW, Descoteaux L, Devries TJ, Reyher KK, Roy JP and Scholl DT (2012). Manageable risk factors associated with the lactational incidence, elimination, and prevalence of Staphylococcus aureus intramammary infections in dairy cows. Journal of Dairy Science, 95: 1283-1300. DOI: https://doi.org/ 10.3168/jds.2011-4711

Dufour S, Fréchette A, Barkema HW, Mussell A and Scholl DT (2011). Invited review: Effect of udder health management practices on herd somatic cell count. Journal of Dairy Science, 94: 563-579. DOI: https://doi.org/ 10.3168/jds.2010-3715.

El-baz R, Rizk DE, Barwa R and Hassan R (2016). Virulence factors profile of Staphylococcus aureus isolated from different clinical sources. N. Egypt. Journal Microbial, 43: 126-144. Available at: https://www.researchgate.net/publication/310494166

El-Diasty ME and El-Kaseh MR (2009). Microbiological studies on raw milk and yoghurt in El-beida City. Research Journal of Animal and Veterinary Sciences, 2: 34-38. Available at: http://www.aensiweb.net/AENSIWEB/rjavs/rjavs/2007/34-38.pdf

El-Gedawy AA, Ahmed HA and Awadallah MAI (2014). Occurrence and molecular characterization of some zoonotic bacteria in bovine milk, milking equipments and humans in dairy farms, Sharkia, Egypt. International Food Research Journal, 21 (5): 1813- 1823. Available at: http://www.ifrj.upm.edu.my

Elmoslemany AM, Keefe GP, Dohoo IR and Dingwell RT (2009a). Microbiological quality of bulk tank raw milk in Prince Edward Island dairy herds. Journal of Dairy Science, 92: 4239-4248. https://doi. org/10.3168/jds.2008-1751. DOI: https://doi.org/ 10.3168/jds.2008-1751

Elmoslemany AM, Keefe GP, Dohoo IR and Jayarao BM (2009b). Risk factors for bacteriological quality of bulk tank milk in Prince Edward Island dairy herds. Part 1: Overall risk factors. Journal of Dairy Science, 92: 2634-2643. DOI: https://doi.org/ 10.3168/jds.2008-1812

Erskine RJ, Eberhart RJ, Hutchinson LJ and Spencer SB (1987). Herd management and Prevalence of mastitis in dairy herds with high and low somatic cell counts. Journal of the American Veterinary Medical Association, 190 (11): 1411-1416. Available at: https://europepmc.org/article/med/3301762

Food and Agriculture Organization (FAO) (2014). Impact of mastitis in small scale dairy production systems. Animal Production and Health Working Paper, No. 13. Rome. Available at http://www.fao.org/3/a-i3377e.pdf

Fox LK (2009). Prevalence, incidence and risk factors of heifer mastitis. Veterinary Microbiology, 134: 82-88. [PubMed: 18930610]. DOI: https://doi.org/ 10.1016/j.vetmic.2008.09.005

Fox LK, Hancock DD, Mickelson A, Britten A and Kaaden OR (2003). Bulk tank milk analysis: factors associated with appearance of Mycoplasma sp. in milk. Journal of Veterinary Medicine, Series B, 50 (5): 235-240. DOI: https://doi.org/ 10.1046/j.1439-0450.2003.00668.x

Gálik Š. Bod'o and Staroňová L (2015). Monitoring the inner surface of teat cup liners made from different materials. Research in Agricultural Engineering, 61: 74-78. DOI: https://doi.org/10.17221/50/2015-RAE.

García-Gil A, Galán-Enríquez CS, Pérez-López A, Nava P, AlpucheAranda C and Ortiz-Navarrete V (2018). SopB activates the Akt-YAP pathway to promote Salmonella survival within B cells, Virulence 9: 1390-1402. DOI: https://doi.org/10.1080/21505594.1509664.

Godefay B and Molla B (2000). Bacteriological quality of raw cow's milk from four dairy farms and a milk collection centre in and around Addis Ababa. Berl Munch Tierarztl Wochenschr, 113: 276-278. Available at: https://www.ncbi.nlm.nih.gov/pubmed/10994252

Godkin MA and Leslie KE (1993). Culture of bulk tank milk as a mastitis screening test: A brief review. Canadian Veterinary Journal, 34 (10): $601-605$. PMID: 17424304. https://www.ncbi.nlm.nih.gov/pubmed/17424304

Godwin D and Moore JA (1997). Manure management in small farm livestock operations; Oregon State University Extension Service: Corvallis, OR, USA, EM 8649. Available at: file:///C:/Users/d.mohamd/Downloads/em8649\%20(1).pdf

Goldberg JJ, Wildman EE, Pankey JW, Kunkel JR, Howard DB and Murphy BM (1992). The influence of intensively managed rotational grazing, rational continuous grazing and confinement housing on bulk tank milk quality and udder health. Journal of Dairy Science, 75: 96-104. DOI: https://doi.org/10.3168/jds.S00220302(92)77743-1.

Gran HM, Mutukumira AN, Wetlesen A and Narvhus JA (2002). Small holder dairy processing in Zimbabwe: Hygienic practices during milking and the microbiological quality of the milk at the farm and on delivery. Food Control, 13: 41-47. DOI: https://doi.org/10.1016/ S0956-7135(01)00082-2.

Green MJ, Leach KA, Breen JE, Green LE and Bradley AJ (2007). National intervention study of mastitis control in dairy herds in England and Wales. Veterinary Record, 160: 287-293. Available at: https://www.ncbi.nlm.nih.gov/pubmed/17337605

Gunn GJ, Heffernan C, Hall M, McLead A and Hovi M (2008). Measuring and comparing constraints to improved biosecurity amongst GB farmers, veterinarians and the auxiliary industries. Prev. Vet. Med., 84: 310-323. [PubMed: 18282623]. Available at: https://www.ncbi.nlm.nih.gov/pubmed/18282623

Hakem A, Benalia R, Khelef D, Laoun A, Fouzia M, Nazek E, Titouche Y and Ben Aissa R (2012). Evaluation of Microbial Quality of Raw Milk into two Dairies Mitidja's Farms (Algeria). Bulletin of the University of Agricultural Sciences and Veterinary Medicine, 69: (1-2). Available at: https://www.researchgate.net/publication/281100752

Halasa T, Huijps K, Osteras O and Hogeveen H (2007). Economic effects of bovine mastitis and mastitis management: A review. Veterinary quarterly, 29: 18-31. DOI: https://doi.org/10.1080/01652176.2007.9695224

Hall BG and Barlow M (2006). Phylogenetic analysis as a tool in molecular epidemiology of infectious diseases. Annals of Epidemiology, 16 (3): 157-169. Available at: DOI: https://doi.org/10.1016/j.annepidem.2005.04.010

Harmon RJ (1994). Physiology of mastitis and factors affecting somatic cell counts. J.ournal of dairy science, 77: 2103-2112. DOI: https://doi.org/10.3168/jds.S0022$\underline{0302(94) 77153-8}$

Harrigan WF (1998). Laboratory methods in food microbiology, $3^{\text {rd }}$ ed., Academic Press, San Diego, p. 198 https://www.emsl.com/Services.aspx?action=list\&TopServiceCategoryID=5\&ServiceCategoryID=5

Hassan L, Mohammed HO, McDonough PL and Gonzalez RN (2000). A cross-sectional study on the prevalence of L. monocytogenes and Salmonella in New York dairy herds. Journal of Dairy Science, 83: 2441-2447. DOI: https://doi.org 10.3168/jds.S0022-0302(00)75135-6

Hoffmann M, Muruvanda T, Allard MW, Korlach J, Roberts RJ, Timme R, Payne J, McDermott PF, Evans P, Meng J, Brown EW Zhao S et al (2013). Complete genome sequence of a multidrug-resistant Salmonella enterica serovar Typhimurium var. 5- strain isolated from chicken breast. Genome Announc., 1 (6): e01068-13. Available at: https://www.ncbi.nlm.nih.gov/nuccore/CP006048. DOI:10.1128/genomeA.01068-13

Hogan JS, Smith KL, Hoblet KH, Schoenberger PS, Todhunter DA, Hueston WD, Pritchard DE, Bowman GL, Heider LG, Brockett BL Conrad HR et al. (1988). Bacteria and somatic cell counts in bulk tank milk from nine well managed herds. Journal of Food Protection, 51: 930. Available at: https://watermark.silverchair.com/0362028x-51_12_930.pdf?

Hogeveen H, Huijps $\mathrm{K}$ and Lam $\mathrm{T}$ (2011). Economic aspects of mastitis: New developments. New Zealand veterinary journal, 59: 16-23. DOI: https://doi.org/10.1080/00480169.2011.547165

Holley RA, Arrus KM and Ominski KH (2006). Salmonella survival in manure-treated soils during simulated seasonal temperature exposure. Journal of environmental quality, 35: 11701180. DOI: https://doi 10.2134/jeq2005.0449

Holm C, Jepsen L, Larsen M and Jespersen L (2004). Predominant microflora od downgraded Danish bulk tank milk. Journal of Dairy Science, 82: 1151-1157. Available at: https://doi.org/10.3168/jds.S0022-0302(04)73263-4

Holt PS, Geden CJ, Moore RW and Gast RK (2007). Isolation of Salmonella enterica serovar Enteritidis from houseflies (Musca domestica) found in rooms containing Salmonella serovar Enteritidis-challenged hens. Applied Environmental Microbioogy, 73: 6030-6035. DOI: https://doi.org/10.1128/AEM.00803-07

Hong YP, Wang YW, Huang IH, Liao YC, Kuo HC, Liu YY, Tu YH, Chen BH, Liao YS and Chiou CS (2018). Genetic relationships among multidrug-resistant Salmonella enterica serovar Typhimurium strains from humans and animals. Antimicrob. Agents Chemother, 62 (5): e00213-e00218. Available at: https://www.ncbi.nlm.nih.gov/nuccore/CP024619.DOI: https://doi.org/10.1128/AAC.00213-18 
Hooton SPT, Timms AR, Rowsell J, Wilson R and Connerton IF (2012). School of Biosciences, Division of Food Sciences, University of Nottingham, Sutton Bonington Campus, Sutton Bonington Near Loughborough, Leicester shire LE12- 5RD, United Kingdom. Available at: https://www.ncbi.nlm.nih.gov/nuccore/CP003836

Howard P (2006). Mastitis pathogens present in bulk tank milk from seven dairy herds in the Waikato region, New Zealand. New Zealand Veterinary Journal, 54 (1): $41-43$. DOI: https://doi.org/10.1080/00480169.2006.36602

Huang TW, Chen FJ, Miu WC, Liao TL, Lin AC, Huang IW, Wu KM, Tsai SF, Chen YT. and Lauderdale TL (2012). Complete genome sequence of Staphylococcus aureus M013, a pvl-positive, ST59-SCCmec type V strain isolated in Taiwan. Journal of Bacteriology, 194 (5): 1256- 1257. DOI: https://doi.org/10.1128/JB.06666-11

Huston CL, Wittum TE, Love BC and Keen JE (2002). Prevalence of fecal shedding of Salmonella spp. in dairy herds. Journal of American veterinary Medical Association, 220: 645-649. DOI: https://doi.org/10.2460/javma.2002.220.645

Hutchison L, Thomas DJI, Moore 1A, Jackson DR and Ohnsta D (2005). An evaluation of raw milk microorganisms as markers of on-farm hygiene practices related to milking. Journal of Food Protection, 68 (4): 764-772. DOI: https://doi.org/10.4315/0362-028x-68.4.764

Hutton CT, Fox LK and Hancock DD (1990). Mastitis control practices: differences between herds with high and low milk somatic cell counts. Journal of Dairy Science, 73: 1135-1143. DOI: https://doi.org/10.3168/jds.S0022-0302(90)78774-7

Ian Ohnstad (2013). Effective cleaning of the milking machine Livestock. Vol. 18. DOI: https://doi.org/10.1111/j.2044-3870.2012.00174.x

International Standard Organization (ISO 707) (2008). Milk and milk products - Guidance on sampling. Available at: https://www.iso.org/obp/ui/\#iso:std:iso:707:ed-3:v1:en

International Standard Organization (ISO. 6888-1 (1999). (last reviewed in 2015). Microbiology of food and animal feeding stuffs - Horizontal method for the enumeration of coagulase-positive staphylococci (Staphylococcus aureus and other species), Part 1: Technique using Baird-Parker agar medium. Available at: https://www.iso.org/obp/ui/\#iso:std:iso:6888:-1:ed-1:v1:en

Intrnational Committee on Microbiological Specifications for foods (ICMSF) (1986). Microorganisms in food, their significance and methods of enumeration $2^{\text {nd }}$ ed.Univ. torontopress, Toronto, Buffalo and London. Available at: http://www.icmsf.org/publications/books

Istituto Zooprofilattico Sperimentale della Lombardia e dell' Emilia Romagna (IZSLER) (2010). http://www.izsler.it/pls/izs_bs/v3_s2ew_consultazione. mostra_pagina?id_pagina=405 Accessed 15 February 2011. Available at: https://www.izsler.it/izs_bs/s2magazine/index1.jsp?idPagina=10

Izumiya H, Sekizuka T, Nakaya H, Taguchi M, Oguchi A, Ichikawa N, Nishiko R, Yamazaki S, Fujita N, Watanabe H et al. (2011). Whole genome analysis of Salmonella enterica serovar Typhimurium T000240 reveals the acquisition of a genomic island involved in multidrug resistance via IS1 derivatives on the chromosome. Antimicrobial Agents and Chemotherapy, 55 (2): 623-630. Available at: https://www.ncbi.nlm.nih.gov/nuccore/AP011957. DOI:10.1128/AAC.01215-10

Jarvik T, Smillie C, Groisman EA and Ochman H (2010). Short-term signatures of evolutionary change in the Salmonella enterica serovar Typhimurium 14028 Genome. Journal of Bacteriology, 192 (2): 560-567. Available at: https://www.ncbi.nlm.nih.gov/nuccore/CP001363. DOI: https://doi.org/10.1128/JB.01233-09

Jayarao BM and Henning DR (2001). Prevalence of foodborne pathogens in bulk tank milk. Journal of Dairy Science, 84: 2157-2162. DOI: https://doi.org/10.3168/jds.S0022-0302(01)74661-9.

Jayarao BM and Wolfgang DR (2003). Bulk-tank milk analysis: A useful tool for improving milk quality and herd udder health. Veterinary Clinics of North America Food Animal, 19 (1): 75-92. DOI https://doi.org/10.1016/s0749-0720(02)00075-0.

Jayarao BM, Donaldson SC, Straley BA, Sawant AA, Hegde NV and Brown JL (2006). A survey of foodborne pathogens in bulk tank milk and raw milk consumption among farm families in Pennsylvania. Journal of Dairy Science, 89: 2451-2458. Available at: https://doi.org/10.3168/jds.S0022-0302(06)72318-9.

Kabagambe EK, Wells SJ, Garber LP, Salman MD, Wagner B and Fedorka-Cray PJ (2000). Risk factors for fecal shedding of Salmonella in 91 US dairy herds in 1996. Preventive Veterinary Medicine, 43 (3): 177-194. DOI: https://doi.org/10.1016/s0167-5877(99)00094-x

Karns JS, Van Kessel JS, McCluskey BJ and Perdue ML (2005). Prevalence of Salmonella enterica in bulk tank milk from US dairies as determined by polymerase chain reaction. Journal of Dairy Science, 88: 3475-3479. Available at: https://doi.org/10.3168/jds.S0022-0302(05)73031-9

Katholm J, Bennedsgaard TW, Koskinen MT and Rattenborg E (2012). Quality of bulk tank milk samples from Danish dairy herds based on real-time polymerase chain reaction identification of mastitis pathogens. Journal of Dairy Science, 95: 5702-5708. DOI: https://doi.org/10.3168/jds.2011-5307

Kauffmann F (1973). Serological diagnosis of Salmonella species. Kaufmann White Scheme, Copenhagen, Denmark, Available at: https://onlinelibrary.wiley.com/doi/abs/10.1111/j.1699-0463.1973.tb00211.x

Keefe GP (2012). Update on control of Staphylococcus aureus and Streptococcus agalactiae for management of mastitis. Veterinary Clinics of North America-Food Animal, 28: 203-216. DOI: https://doi.org/10.1016/j.cvfa.2012.03.010

Keefe GP, Dohoo IR and Spangler E (1997). Herd prevalence and incidence of Streptococcus agalactiae in the dairy industry of Prince Edward Island. Journal of Dairy Science, 80: 464-470. Available at: https://doi.org/10.3168/jds.S0022-0302(97)75958-7

Khin Zar Lin (2015). Isolation and identification of Escherichia coli and Staphylococcus aureus in raw milk samples collected from Lewe, Pyinmana and Takone Townships. MVSc Thesis, University of Veterinary Science, Myanmar. Available at: https://escientificpublishers.com/

Khudor MH, Abbas BA and Idbeis HI (2012). Detection of enterotoxin genes of Staphylococcus aureus isolates from raw milk. Basrah journal of veterinary research, 11 (1): 254-264. Available at: https://www.iasj.net/iasj?func=fulltext\&aId=54852

Kingsley RA, Whitehead S, Connor T, Barquist L, Sait L, Holt KE, Sivaraman K, Wileman T, Goulding D, Clare S, et al. (2013). Submitted (13-JUN-2013): Pathogen Sequencing Unit, Wellcome TrustSanger Institute, Wellcome Trust Genome Campus, Hinxton,Cambridgeshire, CB10 1SA, UNITED KINGDOM. Available at: https://www.ncbi.nlm.nih.gov/nuccore/HG326213

Koneman EW, Allen SD, Janda WM, Schreckenberger PC and WinnJr WC (1997). Color atlas and textbook of diagnostic microbiology, JB Lippincott, Philadelphia, 1395 Available at: https://www.amazon.co.uk/Konemans-Color-Textbook-Diagnostic-Microbiology/dp/0781730147

Kroger C, Dillon SC, Cameron AD, Papenfort K, Sivasankaran SK, Hokamp K, Chao Y, Sittka A, Hebrard M, Handler K, et al. (2012). The transcriptional landscape and small RNAs of Salmonella enterica serovar Typhimurium. Proceedings of the National Academy of Sciences, U.S.A. 109 (20): E1277-E1286. Available at https://www.uniprot.org/citations/22538806

Krzyś A, Luberański A, Szlachta J and Wiercioch M (2011). Dependencies of elasticity changes and geometric parameters on tension force on liners used for milking. Agricultural Engineering, 7: 45-55. Available at: https://pdfs.semanticscholar.org/71a2/29d7f7ef668b147f309180a01c4312c3ebda.pdf

Lee SHI, Camargo CH, Gonçalves JL, Cruz AG, Sartori BT, Machado MB and Oliveira CAF (2012). Characterization of Staphylococcus aureus isolates in milk and the milking environment from small-scale dairy farms of São Paulo, Brazil, using pulsed-field gel electrophoresis Journal of Dairy Science., 95: 7377-7383. DOI https://doi.org/10.3168/jds.2012-5733

Leslie KE (1996). Somatic cell counts: Interpretation for individual cows. Ontario factsheet, Agdex: 410/662. Available at: http://www.omafra.gov.on.ca/english/livestock/dairy/facts/84-012.htm

Lievaart JJ, Barkema HW, Kremer WDJ, Van den Broek J, Verheijden JHM and Heesterbeek JAP (2007). Effect of herd characteristics, management practices, and season on different categories of the herd somatic cell count. Journal of Dairy Science, 90: 4137-4144 DOI: https://doi.org/10.3168/jds.2006-847

Lo CW, Lai YK, Liu YT, Gallo RL and Huang CM (2011). Staphylococcus aureus hijacks a skin commensal to intensify its virulence: Immunization targeting $\beta$-hemolysin and camp factor. Journal Investment. Dermatology, 131 (2): 401 - 409. Available at: http://xdyfyxzz.paperopen.com/OA/pdfdow.aspx?Sid=20150523

Luo Y, Kong Q, Yang J, Golden G, Wanda SY, Jensen RV, Ernst PB and Curtiss R (2011). III. Submitted (22-MAR-2011) Arizona State University, The BiodesignInstitute, 1001 S. McAllister Avenue, Tempe, AZ 85287, USA. Available at: https://www.ncbi.nlm.nih.gov/nuccore/CP002614

Maeda M, Shoji H, Shirakura T, Takuma T, Ugajin K, Fukuchi K, Niki Y and Ishino K (2016). Analysis of staphylococcal toxins and clinical outcomes of methicillinresistant Staphylococcus aureus bacteremia. Biological and Pharmaceutical Bulletin, 39: 1195-200. DOI: https://doi.org/10.1248/bpb.b16-00255

Makovec JA and Ruegg PL (2003). Results of milk samples submitted for microbiological examination in Wisconsin from 1994 to 2001. Journal of Dairy Science, 86: 3466-3472. DOI: https://doi.org/10.3168/jds.S0022-0302(03)73951-4

Mannala G, Domann E and Alt V (2017). Direct Submission: Submitted (02-JUL-2017) Laboratory for Experimetal Trauma Surgery, Justus Liebig University, Schubert Street 81, Giessen 35392, Germany. Available at: https://www.ncbi.nlm.nih.gov/nuccore/CP022290

Manyi-Loh CE, Sampson N, Mamphweli, Edson L, Meyer, Golden Makaka, Michael Simon and Okoh AI (2016). An overview of the control of bacterial pathogens in cattle manure. International Journal of Environmental. Research. Public Health, 13: 843. DOI: https://doi.org/ 10.3390/ijerph13090843

Marcus SL, Knodler LA and Finlay BB (2002). Salmonella enterica serovar Typhimurium effector SigD/SopB is membrane associated and ubiquitinated inside host cells. Cell Microbiology, 4: 435-446. DOI: https://doi.org/ 10.1046/j.1462-5822.2002.00202.x 
Marcus SL, Wenk MR, Steele-Mortimer O and Finlay BB (2001). A synaptojanin-homologous region of Salmonella Typhimurium SigD is essential for inositol phosphatase activity and Akt activation. FEBS Lett., 494: 201-207. DOI: https://doi.org/10.1016/S0014-5793(01)02356-0

Mather AE, Reid SW, Maskell DJ, Parkhill J, Fookes MC, Harris SR, Brown DJ, Coia JE, Mulvey MR, Gilmour MW, et al. (2013). Distinguishable epidemics of multidrugresistant Salmonella Typhimurium DT104 in different hosts. Science, 341 (6153): 1514-1517. Available at: https://www.ncbi.nlm.nih.gov/nuccore/HF937208. DOI: $10.1126 /$ science. 1240578

Meshref AMS (2013). Bacteriological quality and safety of raw cow's milk and fresh cream. Slovak. Veterinary Research, 50 (1): 21-30. Available at: https://www.researchgate.net/publication/286054404

Meyer F, Girardot R, Piemont Y, Prevost G and Colin DA (2009). Analysis of the specificity of Panton-Valentine leucocidin and gamma hemolysin F component binding. Infectious Immunity, 77: 266-273. DOI: https://doi.org/ 10.1128/IAI.00402-08.

Middleton JR (2013). Staphylococcus aureus mastitis: have we learned anything in the last 50 years? Proceedings of the National Mastistis Council Regional Meeting, Portland, Maine, pp.1-8. Available at: https://www.thecattlesite.com/articles/3948/

Minogue T, Wolcott M, Wasieloski L, Aguilar W, Moore D, Tallon L, Sadzewicz L, Ott S, Zhao X, Nagaraj S, Vavikolanu K, Aluvathingal J, Nadendla S Sichtig H et al (2017). Center for Devices and Radiological Health, US Food and Drug Administration, 10903 New Hampshire Avenue, Silver Spring, MD 20993-0002, USA Available at: https://www.ncbi.nlm.nih.gov/nuccore/CP023500

Miranda-Morales RE, Rojas-Trejo V, Segura-Candelas R, Carrillo-Casas EM, SánchezGonzález MG, Castor RS and Trigo-Tavera FJ (2008). Prevalence of pathogens associated with bovine mastitis in bulk tank milk in Mexico. Annals of the New York Academy of Sciences, 1149: 300- 302. DOI https://doi.org/10.1196/annals.1428.012

Mirold S, Ehrbar K, Weissmu“ller A, Prager R, Tscha"pe H, Ru“ssmann H and Hardt WD (2001). Salmonella host cell invasion emerged by acquisition of a mosaic of separate genetic elements, including Salmonella pathogenicity island 1 (SPI1), SPI5, and sopE2. Journal of Bacteriology, 183: 2348-2358. DOI: https://doi.org/10.1128/JB.183.7.2348-2358.2001

Morse D, De Lorenzo MA, Wilcox CJ, Collier RJ, Natzke RP and Bray DR (1988). Climatic effects on occurrence of clinical mastitis. Journal of Dairy Science, 71: 848-853. DOI: https://doi.org/10.3168/jds.S0022-0302(88)79626-5

Murinda SE, Nguyen LT, Ivey SJ, Gillespie BE, Almeida RA, Draughon FA and Oliver SP (2002). Molecular characterization of Salmonella spp. isolated from bulk tank milk and cull dairy cow fecal samples. Journal of Food Protection, 65: 1100-1105. DOI: https://doi.org/10.4315/0362-028x-65.7.1100

Murphy SC and Boor KJ (2000). Trouble-shooting sources and causes of high bacteria counts in raw milk. Dairy, food, and environmental sanitation, 20: 606-611. Available at: https://www.cabdirect.org/cabdirect/abstract/20000405566

Murphy SC and Boor KJ (2007). Sources and causes of high bacteria counts in raw milk: an abbreviated review, Available at: https://dairy-cattle.extension.org/

Nangamso BC (2006). General hygiene of commercially available milk in the Bloemfontein area. p. 127 Available https://pdfs.semanticscholar.org/7387/3a327f9aac5188c1030d909064bc12d560eb.pdf

National Mastitis Council (NMC) (2001). National Mastitis Council recommended mastitis control program. Available at: http://www.nmconline.org/docs/ NMCchecklistInt.pdf.

Neder VE, Canavesio VR and Calvinho LF (2011). Presence of entero-toxigenic Staphylococcus aureus in bulk tank milk from Argentine dairy farms. Revista Argentina deMicrobiola, 43 (2): 104-106. DOI: https://doi.org/10.1590/S0325-75412011000200006

Nickerson SC (2014). Management strategies to reduce heat stress, prevent mastitis and improve milk quality in dairy cows and heifers. University of Georgia, Bulletin 1426. Available on line: http://extension.uga.edu/publications/detail.cfm?number=B1426.

Nielsen LR, Warnick LD and Greiner M (2007). Risk factors for changing test classification in the Danish surveillance program for Salmonella in dairy herds. Journal of Dairy Science, 90: 2815-2825. DOI: https://doi.org/10.3168/jds.2006-314

Nöremark M, Sternberg Lewerin S, Ernholm L and Frössling J (2016). Swedish farmers' opinions about biosecurity and their intention to make professionals use clean protective clothing when entering the stable. Frontiers in veterinary science, 3: 46-46. DOI: https://doi.org/10.3389/fvets.2016.00046

Norman HD, Miller RH, Wright JR and Wiggans GR (2000). Herd and state means for somatic cell count from dairy herd improvement. Journal of Dairy Science, 83: 27822788. DOI: https://doi.org/10.3168/jds.S0022-0302(00)75175-7.

O' Donnell ET (1995). The incidence of Salmonella and Listeria in raw milk from farm bulk tanks in England and Wales. Journal of the Society of Dairy Technology, 18: 25-29. Available at: https://onlinelibrary.wiley.com/doi/epdf/10.1111/j.1471-0307.1995.tb02433.x

O' Connor CB (1995). Rural Dairy Technology. ILRI Training Manual No.1. International Livestock Research Institute (ILRI), Addis Ababa, Ethiopia. Available at: http://dairyasiathailand.dpo.go.th/wp-content/uploads/2016/10/30-ILRI-Training-Manual-1-Rural-Dairy-Technology.

O'Reilly K, Green M and Peeler E (2006). Investigation of risk factors for clinical mastitis in British dairy herds with bulk milk somatic cell counts less than 150,000 cells/ ml. Veterinary Record, 158: 649-653. DOI: https://doi.org/10.1136/vr.158.19.649

Olde Riekerink RG, Barkema HW, Scholl DT, Poole DE and Kelton DF (2010). Management practices associated with the bulk-milk prevalence of Staphylococcus aureus in Canadian dairy farms. Preventive Veterinary Medicine, 97: 20-28. DOI: https://doi.org/10.1016/j.prevetmed.2010.07.002

Olde Riekerink RGM, Barkema HW and Stryhn H (2007). The effect of season on somatic cell count and the incidence of clinical mastitis. Journal of Dairy Science, 90: 1704-1715. DOI: https://doi.org/10.3168/jds.2006-567

Oleggini GH, Ely LO and Smith JW (2001). Effects of region and herd size on dairy herd performance parameters. Journal of Dairy Science, 84 (5): 1044-1050. DOI https://doi.org/10.3168/jds.S0022-0302(01)74564-X

Pangloli P, Dje Y, Ahmed O, Doane CA, Oliver SP and Draughon FA (2008). Seasonal incidence and molecular characterization of Salmonella from dairy cows, calves, and farm environment. Foodborne pathogens and disease, (5): 1. DOI: https://doi.org/10.1089/fpd.2008.0048

Pantoja JCF, Hulland C and Ruegg PL (2009). Dynamics of somatic cell counts and intramammary infections across the dry period. Preventive Veterinary Medicine, 90: 43-54. DOI: https://doi.org/10.1016/j.prevetmed.2009.03.012

Pantoja JCF, Reinemann DJ and Ruegg PL (2009). Association among milk quality indicators in raw bulk tank milk. Journal of Dairy Science, 92: 4978-4987. DOI: https://doi.org/10.3168/ids.2009-2329.

Parker CT, Huynh S and Gorski L (2017). Complete genome sequence of Salmonella enterica subsp. enterica str. RM11060. Submitted (01-AUG-2017), Produce Safety and Microbiology Research Unit, United States Department of Agriculture, Agricultural Research Service, 800 Buchanan St., USDA ARS, Albany, CA 94710, USA Available at: https://www.ncbi.nlm.nih.gov/nuccore/CP022658

Pathogen Informatics (2017). Direct Submission Submitted (15-FEB-2017) WTSI, Pathogen Informatics, Wellcome Trust Sanger Institute, CB10 1SA, United Kingdom. Available at: https://www.ncbi.nlm.nih.gov/nuccore/LT795114

Patterson SK, Borewicz K, Johnson T, Xu W and Isaacson RE (2012). Characterization and differential gene expression between two phenotypic phase variants in Salmonella enterica serovar Typhimurium. PloS ONE, 7 (8): E43592. DOI: https://doi.org/10.1371/journal.pone.0043592

Peles F, Wagner M, Varga L, Hein, Rieck P, Gutser K, Keresztúri P, Kardos G, Turcsányi I, Béri Szabó A et al. (2007). Characterization of Staphylococcus aureus strains isolated from bovine milk in Hungary. Internationa Journal of Food Microbiology, 118: 186-193. Available at: https://doi.org/10.1016/j.ijfoodmicro.2007.07.010

Petersson-Wolfe C, Mullarky I and Jones G (2010). Staphylococcus aureus mastitis: cause, detection, and control. College of Agriculture and Life Sciences, Virginia State University, pp. 404-229. Available online: http://pubs.ext.vt.edu/404/404-229/404-229_pdf.

Phuektes P, Browning GF, Anderson G and Mansell PD (2003). Multiplex polymerase chain reaction as a mastitis screening test for Staphylococcus aureus, Streptococcus agalactiae, Streptococcus dysgalactiae and Streptococcus uberis in bulk milk samples. Journal of Dairy Research, 70: 149-155. DOI https://doi.org/10.1017/s0022029903006010

Piccinini R, Cesaris L, Dapra V, Borromeo V, Picozzi C, Secchi C and Zecconi A (2009). The role of teat skin contamination in the epidemiology of Staphylococcus aureus intramammary infections. Journal of Dairy Research, 76: 36-41. DOI: https://doi.org/10.1017/S0022029908003671

Piepers S, Peeters K, Opsomer G, Barkema HW, Frankena K and de Vliegher S (2011). Pathogen group specific risk factors at herd, heifer and quarter levels for intramammary infections in early lactating dairy heifers. Preventive Veterinary Medicine, 99: 91-101. DOI:10.1016/j.prevetmed.2011.02.010

Quinn PJ, Markey BK, Carter ME, Donnelly WJC, Leonard FC and Maguire D (2002). Veterinary Microbiology and Microbial Diseases. $1^{\text {st }}$ published Blackwell Science ltd. Available at: https://www.wiley.com/enus/Veterinary+Microbiology+and+Microbial+Disease\%2C+2nd+Edition-p-9781405158237 
Reinemann DJ, Bade RD and Thompson PD (2008). Method for assessing teat and udder hygiene. Paper No. 083796. In: ASABE Annual International Meeting. Providence, Rhode Island. Available at: https://milkquality.webhosting.cals.wisc.edu/wp-content/uploads/sites/212/2011/09/

Reinemann DJ, Wolters G and Rasmussen MD (2000). Review of practices for cleaning and sanitation of milking machines www.uwex.edu/uwmril/pdf/milkmachines/cleaning/00_nagano_cip. pdf Nov.2007.Availableat:https://www.oxidationtech.com/downloads/Tech/Milk\%20machine\%20disinfection\%20practices\%20non-O3.pdf

Richardson EJ, Limaye B, Inamdar H, Datta A, Manjari KS, Pullinger GD, Thomson NR, Joshi RR, Watson M and Stevens MP (2011). Genome sequences of Salmonella enterica serovar Typhimurium, choleraesuis, dublin, and gallinarum strains of well- defined virulence in food-producing animals. Journal of Bacteriology, 193 (12): 3162-3163. Available at: https://www.ncbi.nlm.nih.gov/nuccore/CP002487 . DOI:10.1128/JB.00394-11

Riekerink RGO, Barkema HW, Kelton DF, Keefe GP and Scholl DT (2006). Risk factors for herd-level infection of contagious mastitis pathogens on Canadian dairy farms. Proceedings of the $11^{\text {th }}$ International Symposium on Veterinary Epidemiology and Economics, Cairns, Australia, p. 598. Available at: www.sciquest.org.nz

Riekerink RGO, Barkema HW, Veenstra S, Poole DE, Dingwell RT and Keefe GP (2006). Prevalence of contagious mastitis pathogens in bulk tank milk in Prince Edward Island, Canadian Veterinary Journal, 47 (6): 567. PMID: 16808229. Available at: https://www.ncbi.nlm.nih.gov/pubmed/16808229

Rodrigues ACO, Caraviello DZ and Ruegg PL (2005). Management of Wisconsin dairy herds enrolled in milk quality teams. Journal of Dairy Science, 88: 2660-2671. Available at: https://www.researchgate.net/publication/7787165

Rohrbach BW, Draughon FA, Davidson PM and Oliver SP (1992). Prevalence of Listeria monocytogenes, Campylobacter jejuni, Yersinia enterocolitica, and Salmonella in bulk tank milk: Risk factors and risk of human exposure. Journal of Food Protection, 55: 93-97. DOI: https://doi.org/10.4315/0362-028X-55.2.93

Ruegg LP (2006). Role of hygienic in efficient milking. WCDS advances in Dairy Technology. 18: 285-293. Available at http://www.barnettdairy.com/docs/Uddercleanliness.pdf

Ruegg PL (2003). Practical food safety interventions for dairy production. Journal of Dairy Science, 86: E1-E9. Available at: https://doi.org/10.3168/jds.S00220302(03)74034-X

Ruegg PL and Dohoo IR (1997). A benefit to cost analysis of the effect of premilking teat hygiene on somatic cell count and intramammary infections in a commercial dairy herd. Canadian Veterinary Journal, 38: 632-636. Available at: https://www.ncbi.nlm.nih.gov/pmc/articles/PMC1576856/

Ruegg PL and Tabone TJ (2000). The relationship between antibiotic residue violations and somatic cell counts in Wisconsin dairy herds. Journal of Dairy Science, 83: 2805-2809. DOI:10.3168/jds.S0022-0302(00)75178-2

Ruzante JM, Lombard JE, Wagner B, Fossler CP, Karns JS, Van Kessel JAS and Gardner IA (2010). Factors associated with Salmonella presence in environmental samples and bulk tank milk from US dairies zoonoses and public health. https://doi.org/10.1111/j.1863-2378.2010.01333.x

Ryman VE, Nickerson SC, Hurley DJ, Berghaus RD and Kautz FM (2013). Influence of horn flies (Haematobia irritans) on teat skin condition, intramammary infection, and serum anti- S. aureus antibody titres in Holstein heifers. Research veterinary science, 95: 343-346. DOI: https://doi.org/10.1016/j.rvsc.2013.04.017

Rysanek D, Babak V and Zouharova M (2007). Bulk tank milk somatic cell count and sources of raw milk contamination with mastitis pathogens. Veterinary Research Institute, Brno, Czech Republic. Veterinarni Medicina, 52 (6): 223-230. Available at: https://www.agriculturejournals.cz/publicFiles/00217.pdf

Saleem AJ (2017). High frequency of hemolysin associated genes among Staphylococcus aureus clinical isolates in Iraq. Journal of Global Pharmacy Technology. 12 (9): 308-314. Available at: www.jgpt.co.in

Sargeant JM, Schukken YH and Leslie E (1998). Ontario bulk milk somatic cell count reduction program: Progress and outlook. Journal of Dairy Science, 81: 1545- 1554. DOI: https://doi.org/10.3168/jds.S0022-0302(98)75720-0

Sartori C, Boss R, Bodmer M, Leuenberger A, Ivanovic I and Graber HU (2017). Sanitation of Staphylococcus aureus genotype B-positive dairy herds: A field study Journal of Dairy Science, 101: 6897-6914. Available at: https://doi.org/10.3168/jds. -13937.

Schewe RL, Wvlqjd DL, Rqwuhudva GR, Rdwvxuv W, Rylduwl QH and Reohorruhd QG (2015). Herd management and social variables associated with bulk tank somatic cell count in dairy herds in the Eastern United States Journal of Dairy Science, 98: 7650-7665. DOI: https://doi.org/10.3168/jds.2014-8840

Schreiner DA and Ruegg PL (2003). Relationship between udder and leg hygiene scores and sub-clinical mastitis. Journal of Dairy Science, 86: 3460-3465. DOI https://doi.org/10.3168/jds.S0022-0302(03)73950-2

Schroeder JW (2009). Mastitis control programs: Milk quality evaluation tools for dairy farmers. AS-1131. North Dakota State University Extension Service, Fargo. Available at: https://library.ndsu.edu/ir/bitstream/handle/10365/5366/as1131.pdf?sequence=1

Schukken YH, Wilson DJ, Welcome F, Garrison-Tikofsky L and Gonzalez RN (2003). Monitoring udder health and milk quality using somatic cell counts. Veterinary Research, 34: 579-596. DOI: https://doi.org/10.1051/vetres:2003028

Secretaría de Agricultura, Ganadería, Pesca y Alimentos (SAGPyA) (2005). Proposal for improving the competitiveness of argentine dairy farms. Secretariat of National Agriculture and Livestock Services. p. 17. Available at: http://www.fao.org/3/al744e/al744e00.pdf

Semenov AV, Van Bruggen AH and Van Overbeek L (2007). Influence of temperature fluctuations on Escherichia coli O157:H7 and Salmonella enterica serovar Typhimurium in cow manure. FEMS Micobiol. Ecol., 60: 419-428. DOI: https://doi.org/10.1111/j.1574-6941.2007.00306.x

Signorini ML, Sequeira GJ, Bonazza JC, Dalla Santina R, Martí LE, Frizzo LS and Rosmini MR (2008). Utilización de micro-organismos marcadores para la evaluación de las condiciones higiénico-sanitarias en la producción primaria de leche. Rev. Cient (Maracaibo), 18: 207-217. Available at: http://ve.scielo.org/scielo.php?script=sci_arttext\&pid=S0798-22592008000200013

Sischo WM, Heider LE, Miller GY and Moore DA (1993). Prevalence of contagious pathogens of bovine mastitis and use of mastitis control practices. Journal of American veterinary medicine Association, 202: 595-600. Available at: https://www.ncbi.nlm.nih.gov/pubmed/8449798

Skrzypek R (2002). Somatic cell count in bulk tank milk in relation to management and technological factors. Medycyna Weterynaryjna, 58: 632-635. Available at: https://www.arch-anim-breed.net/46/405/2003/aab-46-405-2003.pdf

Skrzypek R, Kamieniecki H, Wo jcik J and Kwiatek A (2003). Factors affecting somatic cell count in milk produced in the area of West Pomerania. 17: 905-908. Available at: https://onlinelibrary.wiley.com/doi/pdf/10.1111/j.1439-0442.2004.00611.x

Skrzypek R, Wo jtowski J and Fahr RD (2004). Factors affecting somatic cell count in cow bulk tank milk - A case study from Poland. Journal of Veterinary Medicine Series A, 51: 127-131. DOI: https://doi.org/10.1111/i.1439-0442.2004.00611.x

Slaghuis BA, Te Giffel MC, Beumer RR and Andre G (1997). Effect of pasturing on the incidence of Bacillus cereus spores in raw milk. International Dairy Journal, 7: 201205. DOI: https://doi.org/https://doi.org/10.1016/S0958-6946(97)00012-5

Sonnier JL, Karns JS, Lombard JE, Kopral CA, Haley BJ, Kim SW, Jo Ann S, Van Kessel et al. (2017). Prevalence of Salmonella enterica, Listeria monocytogenes, and pathogenic Escherichia coli in bulk tank milk and milk filters from US dairy operations in the National Animal Health Monitoring System Dairy 2014 Study. Journa of Dairy Science, 101:1943-1956. Available at : https://doi.org/10.3168/jds.2017-13546

Steele ML, McNab WB, Poppe C and Griffiths MW (1997). Survey on Ontario bulk tank raw milk for food-borne pathogens. Journal of Food Protection, 60: 1341-1346. DOI: https://doi.org/10.4315/0362-028X-60.11.1341

Stephan R, Annemuller C, Hassan AA and Lammler C (2001). Characterization of enterotoxigenic Staphylococcus. aureus strains isolated from bovine mastitis in northeast swizerland. Veterinary Microbiology, 78: 373-382. DOI: https://doi.org/10.1016/s0378-1135(00)00341-2

Stephan R, Buehler K and Lutz C (2002). Prevalence of genes encoding enterotoxins, exfoliative toxins and toxic shock syndrome toxin 1 in Staphylococcus aureus strains isolated from bulk-tank milk samples in Switzerland. Milchwissens chaft, 57: 502-504. Available at: http://www.speciation.net/Database/Journals/Milchwissenschaft-Milk-Science-International-;i404

Summer A, Sandri S, Francheschi P, Malacarne M, Formaggioni P and Mariani P (2007). Seasonal trend of some parameters of the milk quality payment for ParmigianoReggiano cheese. Italian Journal of Animal Science, 6: 475-477. Available at: https://www.researchgate.net/publication/44121884

Tadich N, Kruze J, Locher G and Greek LE (2003). Risk factors associated with BMSCC greater than 200,000 cells/ml in dairy herds in southern Chile. Preventive Veterinary Medicine, 58: 15-24.

Tajbakhsh F, Tajbakhsh E, Rahimi E and Momenii M (2013). Determination of antibiotic resistance in Salmonella Spp. isolated from raw cow, sheep and goat's milk in chaharmahal va bakhtiyari provience, Iran. Global Veterinaria, 10 (6): 681-685. Available at: DOI: https://doi.org/10.5829/idosi.gv.2013.10.6.73138

Tamura K, Stecher G, Peterson D, Filipski A and Kumar S (2013). MEGA6: molecular evolutionary genetics analysis version 6.0. Molecular Biology and Evolution, 30: 2725-2729. DOI: https://doi.org/10.1093/molbev/mst197 
Tarazi YH and Abo-Shehada MN (2015). Herd- and individual-level prevalences of and risk factors for Salmonella spp. fecal shedding in dairy farms in Al-Dhulail Valley, Jordan. Tropical Animal Health and Production, 47 (7): 1241-1248. DOI: https://doi.org/10.1007/s11250-015-0854-Z

Tasci F (2011). Microbiological and chemical properties of raw milk consumed in burdur. Journal of Animal and Veterinary Advances, 10: 635-641. Available at: DOI: https://doi.org/10.3923/javaa.2011.635.641

Thompson JD, Higgins DG and Gibson TJ (1994). CLUSTAL W: improving the sensitivity of progressive multiple sequence alignment through sequence weighting, position- specific gap penalties and weight matrix choice. Nucleic Acids Research, 22 (22): 4673-4680. DOI: https://doi.org/10.1093/nar/22.22.4673

Thomson JL, Yeater KM, Zurek L and Nayduch D (2017). Abundance and accumulation of Escherichia coli and Salmonella Typhimurium procured by male and female house flies (Diptera: Muscidae) exposed to cattle manure. Annals of the Entomological Society of America, 110: 37-44. DOI: https://doi.org/ 10.1093/aesa/saw082

Thrusfield M (2005). Veterinary Epidemiology, $2^{\text {nd }}$ ed. Black well science Ltd. London. pp. 182-198. Available at: https://www.scirp.org/(S(czeh2tfqyw2orz553k1w0r45))/reference/ReferencesPapers.aspx?ReferenceID=606318

Topley CC and Wilson (1990). Principles of Bacteriology, Virology and Immunology. $8^{\text {th }}$ ed. Vol. 3. Edward Arnold Pub. Ltd., 216: 490-503. Available at :https://www.amazon.com/Wilsons-Principles-Bacteriology-Virology-Immunity/dp/0713145943

Uddin MA, Motazzim ul Haque HM and Noor R (2011). Isolation and identification of pathogenic Escherichia coli, Klebsiella spp. and Staphylococcus spp. in raw milk samples collected from different areas of Dhaka City, Bangladesh. Stamford Journal of Microbiology, 1: 19-23. DOI: http://dx.doi.org/10.3329/sjm.v1i1.9098

United States Department of Agriculture (USDA) (2008). Prevalence of contagious mastitis pathogens on U.S dairy, operations. Available at: http://www.aphis.usda.Gov/animal health/nahms/dairy/downloads/dairy07/Dairy07 is_Cont.

United States Department of Agriculture (USDA) (2011). Notice to the industry. European Union Health Certification Program. USDA Agricultural Marketing Service. Available at: http://www.ams.usda.gov/AMSv1.0/getfile?dDocName=STELPRD3636640. [accessed 24 September 2013].

United States Department of Agriculture (USDA) (2013). National Agricultural Statistics Service Agricultural Statistics. Available at:https://www.nass.usda.gov/Publications/Ag_Statistics/2013/Agricultural_Statistics_2013.

Vaessen MA, Veling J, Frankena K, Graat EA and Klunder T (1998). Risk factors for Salmonella dublin infection on dairy farms. The Veterinary Quarterly, 20: 97-99. DOI: https://doi.org/10.1080/01652176.1998.9694848

Van Kessel JA, Karns JS and Wolfgang DR (2008). Environmental sampling to predict fecal prevalence of Salmonella in an intensively monitored dairy herd. Journal of Food Protection, 71: 1967-1973. Available at: https://doi.org/10.4315/0362-028X-71.10.1967.

Van Kessel JA, Karns JS, Gorski L, McCluskey BJ and Perdue ML (2004). Prevalence of Salmonellae, Listeria monocytogenes and fecal coliforms in bulk tank milk on U.S. dairies. Journal of Dairy Science, 87: 2822-2830. Available at: https://doi.org/10.3168/jds.S0022-0302(04)73410-4.

Van Kessel JA, Karns JS, Lombard JE and Kopral CA (2011). Prevalence of Salmonella enterica, Listeria monocytogenes, and Escherichia coli virulence factors in bulk tank milk and in-line filters from U.S. dairies. Journal of Food Protection, 74 (5): 759-768. Available at: DOI: https://doi.org/10.4315/0362-028X.JFP-10-423.

Van Schaik G, Lotem M and Schukken YH (2002). Trends in somatic cell counts, bacterial counts and antibiotic residue violations in New York State during $1999-2000$. Journal of Dairy Science, 85 (4): 782-789. DOI:10.3168/jds.S0022-0302(02)74136-2

Vandenesch F, Lina G and Henry T (2012). Staphylococcus aureus hemolysins, bicomponent leukocidins, and cytolytic peptides: a redundant arsenal of membranedamaging virulence factors?. Frontiers in Cellular and Infection Microbiology, 2: 12. DOI: https://doi.org/10.3389/fcimb.2012.00012

Vanselow BA, Hornitzky MA, Walker KH, Eamens GJ, Bailey GD, Gill PA, Coates K, Corney B, Cronin JP and Renilson S (2007). Salmonella and on-farm risk factors in healthy slaughter-age cattle and sheep in eastern Australia. Australian Veterinary Journal, 85 (12): 498-502. DOI: https://doi.org/10.1111/j.1751-0813.2007.00233.x

Villarroel A, David A, Dargatz V, Michael L, Brian J, McCluskey and Salman M (2017). Suggested outline of potential critical control points for biosecurity and biocontainment on large dairy farms. Journal of the American Veterinary Medical Association, Available at: https://avmajournals.avma.org/loi/javma

Vissio C, Dieser S, Giraudo J, Pellegrino M, Frola I, Raspanti C, Odierno L and Larriestra A (2008). Prevalence of mastitis in dairy farms of the dairy basin of Villa María, Córdoba, Argentina. Argentine congress of animal production, 28: 303-334. DOI: https://doi.org/10.1007/s12602-017-9383-6

Wagner AM and Ruegg PL (2002). The effect of manual forestripping on milking performance of Holstein dairy cows. Journal of Dairy Science., 85: 804-809. https://doi.org/10.3168/ids.S0022-0302(02)74139-8

Warnick LD, Crofton LM, Pelzer KD and Hawkins MJ (2001). Risk factors for clinical salmonellosis in Virginia, USA cattle herds. Preventive Veterinary Medicine, 49: 259-275. DOI: https://doi.org/10.1016/s0167-5877(01)00172-6

Warnick LD, Kaneene JB, Ruegg PL, Wells SJ, Fossler C, Halbert L and Campbell A (2003). Evaluation of herd sampling for Salmonella isolation on Midwest and Northeast US dairy farms. Preventive Veterinary Medicine, 60: 195-206. DOI: https://doi.org/10.1016/s0167-5877(03)00141-7

Wenz JR, Jensen SM, Lombard JE, Wagner BA and Dinsmore RP (2007). Herd management practices and their association with bulk tank somatic cell count on United States dairy operations. Journal of Dairy Science, 90: 3652-3659. DOI: https://doi.org/10.3168/jds.2006-592

Yagoub SO, Awadalla NE and El zubeir MI (2005). Incidence of some potential pathogens in raw milk in khartoum north (Sudan) and their susceptibility to antimicrobial agents. Journal of animal and veterinary advances, 4 (3): 356-359. Available at: https://medwelljournals.com/abstract/?doi=javaa.2005.341.344

Yamaguchi T, Suzuki S, Okamura S, Miura Y, Tsukimori A, Nakamura I, Ito N, Masuya A, Shiina T and Matsumoto T (2015). Evolution and single-nucleotide polymorphisms in methicillin-resistant Staphylococcus aureus strains with reduced susceptibility to vancomycin and daptomycin, based on determination of the complete genome Antimicrob. Agents Chemotheraby, 59 (6): 3585-3587. Available at : https://www.ncbi.nlm.nih.gov/nuccore/AP014652 .DOI:10.1128/AAC.05159$\underline{14}$

Zecconi A (2006). Can we eradicate Staphylococcus aureus mastitis? Proceedings of the $24^{\text {th }}$ World Buiatrics Congress, October 15- 19, Nice, France, pp. 225-236. Available at: http://www.ivis.org/proceedings/wbc/wbc2006/zecconi.pdf?LA=1

Zecconi A, Casirani G, Binda E and Piccinini R (2002). The importance to assess the effects of voluntary milking system on teat tissues, intramammary infections and somatic cell counts. Dept. Anim. Path-infect. Dis. Lab., University of Mailan. Delaval Hygiene, Technology center, Inaugal symposium. Available at: https://scindeks-clanci.ceon.rs/data/pdf/1450-9156/2015/1450-91561503349B.pdf

Zecconi A, Francesca D O, Nicoletta R, Diego V, Micaela C, Paolo P and Lucio Z (2020). Cross-sectional study on the prevalence of contagious pathogens in bulk tank milk and their effects on somatic cell counts and milk yield. Italian Journal of Animal Science, 19 (1): 66-74. Available at: https://doi.org/10.1080/1828051X.2019.1693282

Zelalem Y, Emmannuelle G and Ameha S (2011). Quality factors that affect Ethiopian milk business: Experiences from zone, Ethiopia. MSc. thesis Haramaya University, Ethiopia. Available at: http://www.fao.org/3/a-aq291e.pdf

Zucali M, Bava L, Tamburini A, Brasca M, Vanoni L and San-drucci A (2011). Effects of season, milking routine and cow cleanliness on bacterial and somatic cell counts of bulk tank milk. Journal Dairy Research, 78: 436-441. DOI: http://www.doi.org/10.1017/S0022029911000598 